NBER WORKING PAPER SERIES

\title{
TRADE AND FOREIGN DIRECT \\ INVESTMENT IN CHINA: \\ A POLITICAL ECONOMY APPROACH
}

\author{
Lee G. Branstetter \\ Robert C. Feenstra \\ Working Paper 7100 \\ http://www.nber.org/papers/w7100 \\ NATIONAL BUREAU OF ECONOMIC RESEARCH \\ 1050 Massachusetts Avenue \\ Cambridge, MA 02138 \\ April 1999
}

We thank Chen Chun-Lai, Wen Hai, David Li, Barry Naughton, Daniel Rosen, Scott Rozelle, Edward Steinfeld, William Skinner, Eric Thun, Shang-Jin Wei, Wing Woo, Alwyn Young and seminar participants at the University of Michigan and the World Bank for helpful comments and suggestions. We are indebted to a large team of research assistants, including Natasha Hsieh, Songhua Lin, Kaoru Nabeshima, Shun-li Yao, and David Yue. Branstetter wishes to thank the Japan Foundation Center for Global Partnership and the Social Science Research Council for financial support of the fieldwork component of this project, and he thanks the many anonymous China-based multinational executives who provided their insights concerning the environment confronting foreign firms in China. He also acknowledges the support of a University of California Faculty Research Grant. Feenstra thanks the National Science Foundation for financial support. All errors are the sole responsibility of the authors. The views expressed herein are those of the authors and do not necessarily reflect the views of the National Bureau of Economic Research.

(- 1999 by Lee G. Branstetter and Robert C. Feenstra. All rights reserved. Short sections of text, not to exceed two paragraphs, may be quoted without explicit permission provided that full credit, including ${ }^{\circledR}$ notice, is given to the source. 
Trade and Foreign Direct Investment in China:

A Political Economy Approach

Lee G. Branstetter and Robert C. Feenstra

NBER Working Paper No. 7100

April 1999

JEL No. F13, F21, O53

\section{ABSTRACT}

We view the political process in China as trading off the social benefits of increased trade and foreign direct investment, against the losses incurred by state-owned enterprises due to such liberalization. A model drawing on Grossman and Helpman $(1994,1996)$ is used to derive an empirically estimable government objective function. The key structural parameters of this model are estimated using province-level data on foreign direct investment and trade flows in China, over the years 1984-1995. We find that the weight applied to consumer welfare is between one-fifth and one-twelfth of the weight applied to the output of state-owned enterprises. We find that governmental preferences have shifted over time, but even in recent periods the weight on consumer welfare is only one-half of the weight on state-owned enterprises. This suggests that China may find it politically difficult to follow through with liberalizing its trade and investment regimes, such as under its WTO accession proposal.

Lee Branstetter

Department of Economics

University of California

Davis, CA 95616

and NBER

branstet@ucdavis.edu
Robert Feenstra

Department of Economics

University of California

Davis, CA 9561

and NBER

rcfeenstra@ucdavis.edu 


\section{Introduction}

In recent years, few developments in international economics have elicited more interest or stirred more controversy than the sudden emergence of China as a trading nation and manufacturing center. ${ }^{1}$ China's high rate of economic growth since the adoption of more liberal economic policies under Deng Xiao-Ping in the late 1970s, while perhaps exaggerated by the official statistics, is nevertheless a stunning accomplishment. ${ }^{2}$ In the space of less than a generation, China has transformed itself from a poor nation almost completely cut off from the global economy to one of the world's most important suppliers of labor-intensive manufactures. Its arrival into the ranks of trading nations will be complete when it is has achieved its intention to join the World Trading Organization (WTO).

Nevertheless, a number of economists have recently called into question the sustainability of China's current rates of GDP and export growth. These observers have tended to point out the shortcomings of China's "socialist market economy," focusing on the inability of the government to raise revenue by taxing the new private economy, the problems the government has encountered in reforming state owned enterprises, the distortions created by China's dualistic trade regime, and the mounting "non performing loans" problem in the Chinese banking sector. ${ }^{3}$ In a striking paper, Alwyn Young (1997) has recently argued that China's high trade/GDP ratio is a sign of intra-national trade barriers rather than international economic openness. Particularly since the onset of the East Asian financial crisis, the consensus has shifted to a more pessimistic outlook for China.

The reality of important distortions in the Chinese economy, and particularly in its international trade regime, is increasingly evident. We offer, in this paper, what is to our

\footnotetext{
${ }^{1}$ For an excellent overview of this emergence, see Naughton (1996).
} 
knowledge the first attempt to use the theoretical models of political economy pioneered by Grossman and Helpman (1994) to analyze these distortions. We view the political process in China as trading off the social benefits of increased trade and foreign direct investment, against the losses incurred by state-owned enterprises due to such liberalization. We write down an explicit theoretical model of the policy formulation process which, we argue, captures important features of Chinese institutional reality. We then use this model to derive an empirically estimable governmental objective function. The key structural parameters of this model are estimated using province-level data on foreign direct investment and trade flows in China in the years 1984-1995.

These estimates allow us to quantify the relative weights placed on "special interests" and general economic welfare. In striking contrast to Goldberg and Maggi’s (1997) results with U.S. data, we find quantitative evidence that Chinese provincial and central governments have given much greater weight to the special interests of state-owned enterprises than to general economic welfare. Moreover, our empirical framework allows us to estimate how the weights in the government's objective function have shifted over time. In other words, we can quantify the extent to which Chinese political economy has become more "market-oriented" over the course of the reform period. Finally, our framework allows us to estimate the impact on governmental utility of proposed changes in China's trade regime. As an experiment, we estimate the impact of the tariff reductions China has offered as part of its bid for WTO accession. The implications of these findings for the political economy literature and for the debate over economic reform in China are discussed in the conclusion. The proofs of propositions are gathered in a separate Appendix.

\footnotetext{
2 See Sachs and Woo (1997) for a discussion with some reference to the problems of official Chinese statistics.

3 Again, Naughton (1996) provides an excellent overview of these issues.
} 


\section{Policies towards Foreign Direct Investment and Trade}

A comprehensive description of Chinese economic reform, even one focused solely on the evolution of China's trade and FDI regime, is well beyond the scope of this paper. The reader is directed to Lardy (1992) and Naughton (1995) for two well-regarded studies. ${ }^{4}$ Here, we quickly summarize some of the most important policy shifts that directly relate to FDI and trade.

The formal ban on foreign direct investment in China was lifted in 1972, in the wake of the visit of U.S. President Richard Nixon to China. This opened the doors for a diplomatic rapprochement between China and several major industrial nations. However, a number of severe restrictions on FDI remained in place - including a ban on external financing of FDI projects - so that there was very little inward investment until policies were dramatically changed in 1979.

By 1979, Deng Xiao-Ping had consolidated his power within the Chinese government and the Communist Party. At his behest, a new Law on Joint Ventures was passed, providing a basic framework under which foreign firms were allowed to operate. Restrictions on external debt and equity finance were relaxed, and controls on foreign trade were reduced. Provincial and local governments were allowed considerable freedom in regulating the joint ventures that were established within their jurisdictions. In the same year, four "special economic zones" (SEZ) were established in which foreign firms were offered preferential tax and administrative treatment, and given an unusually free hand in their operations. ${ }^{5}$ In particular, these zones charged a reduced tax of $15 \%$ on business income of foreign affiliated firms (as compared to $33 \%$ for domestic firms), but these taxes were not levied during the first two years of operation

4 The material in this section also draws on Grub and Lin (1991) and Pomfret (1991).

5 These SEZs included Shenzhen (across the border from Hong Kong), Zhuhai (across the border from Macau), Shantou (on the Guangdong coast facing Taiwan) and Xiamen (directly across the Taiwan Straits from Taiwan). 
and charged at one-half of the full rate in the third through fifth years. ${ }^{6}$ In addition, wholly foreign owned enterprises were permitted for the first time. It is important to recognize that none of the original special economic zones were developed industrial centers in 1979. In fact, these zones were established outside the state's industrial centers to prevent "contamination" of Chinese heavy industry by outside influences. These "experiments" in attracting foreign direct investment were quite successful. In 1984, fourteen additional areas known as "open coastal cities", were granted similar exemptions from taxes and administrative procedures in a bid to attract FDI. ${ }^{7}$ These cities levied a tax rate of $24 \%$ on foreign affiliated firms, and were granted local authority to approve foreign investment for projects under $\$ 30$ million (now $\$ 50$ million).

The end of the 1970s and early 1980s also marked a period of profound reform in Chinese trade policy. Up through the 1970s, Chinese trade was essentially monopolized by twelve state-owned trading companies, each with responsibility for a different set of commodities. Trade took place within the context of a planned economy and therefore all trade was subject to very exacting quantitative barriers. The state monopoly on foreign trade was ended at the end of the 1970s, and what came to replace it by the mid 1980s were, in essence, two separate trading regimes - one for the foreign-invested enterprises (FIEs) and one for "native" Chinese enterprises. ${ }^{8}$ The trade regime under which the FIEs operated was by far the more liberal. Unlike domestic enterprises, which had to import and export through state-owned foreign trade companies, FIEs were allowed to engage in international trade directly. In addition, export-oriented FIEs were allowed duty-free import of raw materials, components, and

\footnotetext{
6 Naughton (1996, p. 301). The discrepancy between the corporate tax for foreign-affiliated and domestic firms has led many Chinese firms to seek foreign partners, sometimes through setting up corporations in Hong Kong. This so-called "round tripping" accounts for some (unknown) fraction of the foreign investment into China.

7 The entire island of Hainan was declared a special economic zone in 1988.

8 Borrowing from the Chinese terminology, Naughton (1996) refers to these two regimes as the "export processing" and "ordinary trade" regimes, respectively and he provides an excellent discussion of them.
} 
capital equipment for export production. They also qualified for concessionary income tax rates and tax holidays.

As noted, domestic firms still had to trade indirectly, obtaining imports and channeling exports through foreign trade companies (FTCs). ${ }^{9}$ To be sure, the original twelve monopolies were broken up, and by the late 1980s there were more than 5,000 FTCs operating throughout China. However, most of these FTCs were limited to trade in certain commodities, operation in a particular province, and were only allowed to service certain kinds of customers. Thus, domestic enterprises seeking to interact with the global economy had to work through a legally mandated, far from perfectly competitive layer of middlemen. On top of this, most domestic imports are not duty-free, so that domestic firms have had to contend with China's formal and informal barriers to trade. While tariffs have come down over the course of the 1980s and 1990s, they are still high. On top of these tariff barriers, some 20 percent of Chinese imports are subject to formal non-tariff barriers

The next major regulatory change in FDI came in 1986, with the implementation of the so-called "Twenty-two Regulations." These changes represented a major liberalization which applied throughout China. Foreign invested enterprises were made eligible for reduced business income tax rates regardless of location, and were given increased managerial autonomy. Tight controls on the remittance of profit in foreign currencies were lifted. In addition, the Twentytwo Regulations designated two categories of foreign investments as being eligible for additional special benefits - "export oriented" projects (defined as projects exporting 50\% or more of their production value) and "technologically advanced" projects (defined as projects which upgrade domestic production capacity through the use of 'advanced' technology).

\footnotetext{
${ }^{9}$ Over time, some larger enterprises were granted independent import rights, but this was generally restricted to larger enterprises.
} 
The Twenty-two Regulations also set up an approval process for foreign direct investment projects which remains in place today, albeit with some modification. The approval process is a complex one involving thirteen agencies and branches of the central government as well as local Foreign Economic Relations and Trade Commissions. While the formal regulatory framework implies substantial centralization of power over the approval process and subsequent regulatory oversight of FIEs, there is considerable debate among China scholars as to how much the central government intervenes in the oversight of FIEs after they are established. In practice, there seems to be a considerable degree of de facto local autonomy in regulating FIEs.

The next major shift in FDI in China marked not so much a regulatory shift as a change in the composition of foreign investors. FDI in China slowed briefly after the events of Tiananmen square in 1989, but resumed and quickly grew in the $1990 \mathrm{~s}^{10}$ Whereas FDI in China in the 1980s had been overwhelmingly dominated by Hong Kong and Taiwan-based investors seeking to exploit relatively low cost labor in the SEZs for export processing, in the 1990s FDI in China increasingly consisted of investments by Western and Japanese multinationals seeking to serve the Chinese market through local production capacity. It is also important to point out that FDI inflows in the post-1990 area were much larger than those of the 1980s, both in absolute quantities and as a percentage of GDP. Finally, in the later 1980s and 1990s, FDI began to flow in significant quantities into the centers of China's (state-owned) heavy industry manufacturing and finance. Of these, Shanghai and the neighboring provinces are the clear standouts.

Figure 1 illustrates the cumulative stock of FDI into China's 30 provinces (not counting the Hong Kong Special Administrative Region) in 1995. The variation across regions is quite

10 Naughton (1996), among others, suggests that there was a de facto loosening of the official regulations on foreign direct investment which allowed multinationals to skirt the official export requirements. Essentially, export requirements were increasingly ignored or the definition of a "technologically advanced" project was broadened to allow even not particularly technology-intensive firms to set up plants to serve the Chinese market. 
striking, with Guangdong province, the site of three of the initial four SEZs, and neighboring Fujian, the site of the fourth, maintaining dominant positions as the most important sites of FIE activity. On the other hand, Shanghai and the surrounding provinces have received very substantial inflows starting from a very low base in the late 1980s, such that they have collectively become the next-largest recipient area by 1995 .

\section{Firm Interviews}

Given the enormous variations in central government policy and regional government implementation across provinces and across time, we felt it was important to obtain some direct qualitative information concerning the regulatory environment on the operations of multinational firms. To this end, one of the authors traveled to China in the winter of 1998, interviewing executives and former executives of more than 20 multinationals, consulting firms, research institutions, and advisory agencies in China. We have also consulted with China experts in the U.S. and in China itself.

One of the most important impressions obtained in China could be summarized as follows: "For every anecdote in China, there is an equal and opposite anecdote." One comes to understand the limits of qualitative field research rather quickly, as the experience of firms varies so widely across industries, provinces, firms, and time. This truth was forcibly driven home to the authors when different firms in the same industry in the same province would tell strikingly different stories about their experience in the Chinese market.

Nevertheless, some consistent themes emerged from our discussions with firm managers, which reinforce some of the key assumptions in our modeling framework. The first is that most of the foreign invested enterprises we interviewed do, in fact, compete with state-owned firms to some degree. In some industries, the FIEs have already collectively obtained a dominant market 
position, such that the state-owned enterprises have been confined to the less profitable low end of the product market.

The second is that the Chinese government, both national and local, is acutely aware of this competition, and has taken steps to impede the ability of foreign firms to compete in the Chinese market. Scholars of the Chinese economy will be familiar with the nexus of restrictions on the operations of multinationals that were described to us by multinational executives. They include export requirements, localization requirements, requirements for technology transfer, restrictions on domestic market access, and difficulties in recruiting and retaining key personnel - a feature of the Chinese economy which is exacerbated by government policy. A number of multinational managers also complained bitterly about attempts by provincial and even local governments to extract funds from foreign firms through both legal and illegal surcharges and taxes. While, on paper, foreign firms get favorable tax and import treatment, in practice, figuring in all of the restrictions and extralegal surcharges, it is clear that, in many cases, foreign firms are operating with a clear, government-engineered disadvantage.

Third, our presumption of limited economic integration among Chinese provinces drawn from Young (1997) - received surprisingly strong support from discussions with expatriate managers and native Chinese executives. While the extent of local protectionism varies across industries, it is seen as a barrier to growth and economic efficiency by nearly every firm we interviewed. As one Shanghai-based advisor to American firms put it, "There is no China market. There are several China markets, and none of them are as big as you think." These various inferences from our firm interviews will be built into the model that we propose to capture the tradeoffs faced by provincial and central authorities, as they consider the policies towards foreign direct investment and trade. 


\section{The Model}

The model we develop draws heavily from Grossman and Helpman (1996), who apply the political-economy framework developed in their 1994 paper to the issue of multinationals. Specifically, they investigate whether the entry of multinationals will affect the level of protection, and conversely, in a model where the domestic industry is making campaign contributions. In our model, we will suppose instead that the domestic industry is owned by the government, which gives extra weight to industry profits in its objective function. ${ }^{11}$ The presence of multinationals presents a potential threat to the state-owned enterprises through product market competition. Li and Chen (1998) use a framework like this to examine the government's ability to extract rents from the multinationals, and we will use policy instruments similar to theirs. Our key findings concerning the shape of the government's objective function, depending on the entry of multinationals, are not developed in either of these related papers, however.

Because some features of our model are familiar, we will try to present it as concisely as possible. The following points summarize the main components:

Regions: We will treat the regions within the country as distinct, following Young's (1997) thesis that the provinces within China have only limited trade with each other. Thus, the model below describes each region, which will differ in terms of their underlying parameters.

Products: Each regional economy produces a numeraire good denoted by $\mathrm{x}_{0}$, and a differentiated product which is a CES aggregate of the various varieties. There are three sources

\footnotetext{
11 As Naughton (1996) and several other authors have noted, the Chinese government still relies on remittances from state-owned enterprises for about two-thirds of its revenue. This is also true at the provincial level. The provincial government of Yunnan is rumored to obtain nearly all of its revenue from the provincial tobacco monopoly.
} 
for the products: $\mathrm{n}_{\mathrm{h}}$ varieties are produced by home firms; $\mathrm{n}_{\mathrm{f}}$ varieties are produced by foreign firms, where $\mathrm{m}$ of these are produced locally by multinationals, and the remaining $\left(\mathrm{n}_{\mathrm{f}}-\mathrm{m}\right)$ are imported into the country.

Consumers: Consumer preferences are given by,

$$
\mathrm{U}=\mathrm{x}_{0}+\left(\frac{\theta}{\theta-1}\right) \mathrm{x}^{(\theta-1) / \theta}, \theta>0, \theta \neq 1,
$$

where the CES aggregate is,

$$
\mathrm{x}=\left[\mathrm{n}_{\mathrm{h}} \mathrm{x}_{\mathrm{h}}^{(\varepsilon-1) / \varepsilon}+\left(\mathrm{n}_{\mathrm{f}}-\mathrm{m}\right) \mathrm{x}_{\mathrm{f}}^{(\varepsilon-1) / \varepsilon}+\mathrm{mx}_{\mathrm{m}}^{(\varepsilon-1) / \varepsilon}\right]^{\varepsilon /(\varepsilon-1)}, \varepsilon>1
$$

The values $x_{j}$ denote consumption of the differentiated varieties from source $j=h$ (home firms), f (imported), and m (multinationals).

Letting $p_{j}$ denote the prices of each goods $j=h, f, m$, we can maximize utility subject to the budget constraint $\mathrm{x}_{0}+\mathrm{n}_{\mathrm{h}} \mathrm{p}_{\mathrm{h}} \mathrm{x}_{\mathrm{h}}+\left(\mathrm{n}_{\mathrm{f}}-\mathrm{m}\right) \mathrm{p}_{\mathrm{f}} \mathrm{x}_{\mathrm{f}}+\mathrm{mp} \mathrm{p}_{\mathrm{m}} \mathrm{x}_{\mathrm{m}}=\mathrm{I}$ to obtain:

$$
\mathrm{x}_{\mathrm{j}}=\mathrm{p}_{\mathrm{j}}^{-\varepsilon} \mathrm{q}^{\varepsilon-\theta}, \mathrm{j}=\mathrm{h}, \mathrm{f}, \mathrm{m}, \text { and } \mathrm{x}=\mathrm{q}^{-\theta} \text {, }
$$

where $\mathrm{q}$ is a price index,

$$
\mathrm{q}=\left[\mathrm{n}_{\mathrm{h}} \mathrm{p}_{\mathrm{h}}^{1-\varepsilon}+\left(\mathrm{n}_{\mathrm{f}}-\mathrm{m}\right) \mathrm{p}_{\mathrm{f}}^{1-\varepsilon}+\mathrm{mp} \mathrm{p}_{\mathrm{m}}^{1-\varepsilon}\right]^{1 /(1-\varepsilon)}
$$

Note the $\varepsilon>1$ is the own-price elasticity of demand for each variety, while $\theta>0$ is the elasticity of demand for the CES aggregate. We add the restriction that $\varepsilon>\theta$, which ensures that the cross-price elasticity for each variety is positive. 
Firms: Costs for the locally produced products are $c_{j}, j=h, m$. Costs for products produced

abroad are $c_{f}$, but also face a specific tariff of $\tau$, so that marginal costs become $c_{f}+\tau$. Then firms at home and abroad maximize profits given by,

$$
\begin{gathered}
\pi_{j}=\left(p_{j}-c_{j}\right) x_{j}, j=h, m, \\
\pi_{f}=\left[p_{f}-\left(c_{f}+\tau\right)\right] x_{h} .
\end{gathered}
$$

Using the demand equations in (3), and optimizing over the choice of $\mathrm{p}_{\mathrm{j}}$, we obtain the prices:

$$
\begin{gathered}
\mathrm{p}_{\mathrm{j}}=\left(\frac{\varepsilon}{\varepsilon-1}\right) \mathrm{c}_{\mathrm{j}}, \mathrm{j}=\mathrm{h}, \mathrm{m}, \\
\mathrm{p}_{\mathrm{f}}=\left(\frac{\varepsilon}{\varepsilon-1}\right)\left(\mathrm{c}_{\mathrm{f}}+\tau\right) .
\end{gathered}
$$

Substituting these prices into (5), we obtain the profits of each type of firm:

$$
\pi_{\mathrm{j}}=\mathrm{p}_{\mathrm{j}} \mathrm{x}_{\mathrm{j}} / \varepsilon, \mathrm{j}=\mathrm{h}, \mathrm{f}, \mathrm{m}
$$

Factors: We will suppose that labor is the only factor of production, and one unit of the numeraire is produced with one unit of labor, so wages are unity. While workers in the home industry producing differentiated products earn unity, we shall assume that the multinational firms pay a wage premium of $(\mathrm{w}-1)>0 .{ }^{12}$ Despite this premium, we will still suppose that is it cheaper for the multinational to supply local demand from local production, than from imports which are subject to the tariff. That is, we assume,

\footnotetext{
12 The existence of this wage premium is strongly confirmed in our data and in our interviews with multinational managers. The managers suggested that, since multinationals typically employ more capital and technology intensive production processes, they require the best workers in the local labor pool. Hence, they pay what the labor literature has referred to as "efficiency wages." Other case studies have documented the need to pay Chinese workers employed in multinationals a wage premium to offset the "envy" created by the even higher wage earned by their American counterparts in these firms.
} 


$$
\mathrm{c}_{\mathrm{m}}<\mathrm{c}_{\mathrm{f}}+\tau
$$

This assumption is needed to ensure that the multinational firms have any interest in entering the local market.

Policy towards multinationals: Each foreign firm faces the decision of whether to supply locally through imports, or through setting up a local plant which requires a fixed cost of $\mathrm{F}>0$. We suppose that the government also charges the multinational an profit tax of $\lambda \geq 0$. This instrument is supposed to reflect the vast range of actual policies used in China to extract rents from multinationals, and not just the nominal tax on multinationals. For example, the fact that most multinationals have had to use local partners reflects an implicit tax on their profits, which are shared with the partner; similarly, the land-use fees that are commonly charged reduce the multinationals' profits. By modeling these policies as a tax on profits, we are abstracting from the inefficiencies caused by actual policies (such as local content restrictions, for example). ${ }^{13}$ This is similar to the "entry fee" used by Li and Chen (1998), and is in the spirit of Grossman and Helpman (1994), who draw on Bernheim and Whinston (1984) to argue that the outcome of political contests can be efficient.

The profits earned locally are thus $(1-\lambda) \pi_{\mathrm{m}}-\mathrm{F}$, with $\pi_{\mathrm{m}}$ defined by (5a) and (6a).

Alternately, the multinational could just export to the home country, and earn $\pi_{\mathrm{f}}$ defined by (5b)

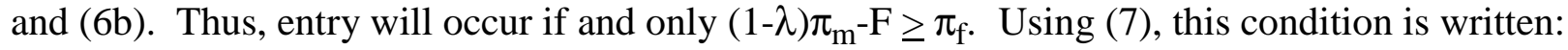

$$
(1-\lambda) \frac{p_{m} x_{m}}{\varepsilon}-F \geq \frac{p_{f} x_{f}}{\varepsilon}
$$

13 Of course, bribes paid to allow multinationals to enter are another example of the profit tax. Wei (1998) argues that corruption in China, which includes the need for "questionable payments", acts as a significant deterrent to foreign direct investment. 
We will assume that when $m=\lambda=0$ then (9) holds as a strict inequality. This means that for some positive $\lambda$, entry of multinationals will occur.

Government Objective Function: We can now state the total returns to each interest group, beginning with consumers/workers, who receive a weight of $\alpha$ in the objective function. It is readily verified that maximized utility from (1) is $U=I+q^{1-\theta} /(\theta-1)$, where I denotes labor income. With $\mathrm{a}_{\mathrm{m}}$ workers used per unit output in the multinationals, the total wage premium is $(\mathrm{w}-1) \mathrm{ma}_{\mathrm{m}} \mathrm{x}_{\mathrm{m}}$. The multinational's price is $\mathrm{p}_{\mathrm{m}}=\mathrm{wa}_{\mathrm{m}} \varepsilon /(\varepsilon-1)$, so the total wage premium can be written $[(\varepsilon-1)(\mathrm{w}-1) / \mathrm{w} \varepsilon] \mathrm{mp}_{\mathrm{m}} \mathrm{x}_{\mathrm{m}}$. Including this within labor income, we obtain utility of,

$$
\begin{aligned}
\mathrm{U} & =\mathrm{L}+\left(\frac{\varepsilon-1}{\mathrm{e}}\right)\left(\frac{\mathrm{w}-1}{\mathrm{w}}\right) \mathrm{mp}_{\mathrm{m}} \mathrm{x}_{\mathrm{m}}+\frac{1}{(\theta-1)} \mathrm{q}^{1-\theta} \\
& =\mathrm{L}+\left(\frac{\varepsilon-1}{\varepsilon}\right)\left(\frac{\mathrm{w}-1}{\mathrm{w}}\right) \mathrm{mp}_{\mathrm{m}} \mathrm{x}_{\mathrm{m}}+\frac{1}{(\theta-1)}\left[\mathrm{n}_{\mathrm{h}} \mathrm{p}_{\mathrm{h}} \mathrm{x}_{\mathrm{h}}+\left(\mathrm{n}_{\mathrm{f}}-\mathrm{m}\right) \mathrm{p}_{\mathrm{f}} \mathrm{x}_{\mathrm{f}}+\mathrm{mp}_{\mathrm{m}} \mathrm{x}_{\mathrm{m}}\right]
\end{aligned}
$$

where $\mathrm{L}$ is the labor endowment of the region. To obtain the second line of (10), we combine (3) and (4) to solve for $\left[n_{h} p_{h} x_{h}+\left(n_{f}-m\right) p_{f} x_{f}+m p_{m} x_{m}\right]=q^{1-\theta}$.

We will suppose that the domestic firms are state-owned, so these profits accrue to the regional and national government. Profits of the domestic firms are $n_{h} \pi_{h}=n_{h} p_{h} x_{h} / \varepsilon$, from (6). We give revenue from state-owned firms a weight $\beta$ in the objective function. Finally, the government extracts rents $m \lambda \pi_{\mathrm{m}}$ from the multinationals, and also collects tariff revenue of $\tau\left(\mathrm{n}_{\mathrm{f}}-\mathrm{m}\right) \mathrm{x}_{\mathrm{f}}$. These two sources of revenue are each given weights of unity.

The objective function for each region is defined as, 


$$
\begin{aligned}
\mathrm{G}(\mathrm{m}, \mathrm{T}, \tau) & \equiv \alpha \mathrm{U}+\beta \mathrm{n}_{\mathrm{h}} \pi_{\mathrm{h}}+\mathrm{m} \lambda \pi_{\mathrm{m}}+\tau\left(\mathrm{n}_{\mathrm{f}}-\mathrm{m}\right) \mathrm{x}_{\mathrm{f}} \\
= & \alpha \mathrm{L}+\left[\frac{\alpha}{(\theta-1)}+\frac{\beta}{\varepsilon}\right] \mathrm{n}_{\mathrm{h}} \mathrm{p}_{\mathrm{h}} \mathrm{x}_{\mathrm{h}}+\left[\frac{\alpha}{(\theta-1)}+\frac{\tau}{\mathrm{p}_{\mathrm{f}}}\right]\left(\mathrm{n}_{\mathrm{f}}-\mathrm{m}\right) \mathrm{p}_{\mathrm{f}} \mathrm{x}_{\mathrm{f}} \\
& +\left[\frac{\alpha}{(\theta-1)}+\frac{\alpha(\varepsilon-1)(\mathrm{w}-1)}{\varepsilon \mathrm{W}}+\frac{\lambda}{\varepsilon}\right] \mathrm{mp}_{\mathrm{m}} \mathrm{x}_{\mathrm{m}},
\end{aligned}
$$

where the equality follows using (10). Several properties of this function are summarized by:

\section{Lemma 1}

$$
\begin{aligned}
\frac{\partial \mathrm{G}}{\partial \mathrm{m}} & =\frac{\left(\mathrm{p}_{\mathrm{m}} \mathrm{x}_{\mathrm{m}}-\mathrm{p}_{\mathrm{f}} \mathrm{x}_{\mathrm{f}}\right)}{(\varepsilon-1)}\left[\alpha-\mathrm{s}_{\mathrm{h}} \frac{\beta(\varepsilon-\theta)}{\varepsilon}\right] \\
& -\left(\frac{\tau}{\mathrm{p}_{\mathrm{f}}}\right)\left\{\mathrm{p}_{\mathrm{f}} \mathrm{x}_{\mathrm{f}}+\mathrm{s}_{\mathrm{f}}\left(\frac{\varepsilon-\theta}{\varepsilon-1}\right)\left(\mathrm{p}_{\mathrm{m}} \mathrm{x}_{\mathrm{m}}-\mathrm{p}_{\mathrm{f}} \mathrm{x}_{\mathrm{f}}\right)\right\} \\
& +\left[\alpha\left(\frac{\varepsilon-1}{\varepsilon}\right)\left(\frac{\mathrm{w}-1}{\mathrm{w}}\right)+\frac{\lambda}{\varepsilon}\right]\left\{\mathrm{p}_{\mathrm{m}} \mathrm{x}_{\mathrm{m}}-\mathrm{s}_{\mathrm{m}}\left(\frac{\varepsilon-\theta}{\varepsilon-1}\right)\left(\mathrm{p}_{\mathrm{m}} \mathrm{x}_{\mathrm{m}}-\mathrm{p}_{\mathrm{f}} \mathrm{x}_{\mathrm{f}}\right)\right\}
\end{aligned}
$$

where $s_{j}, j=h, f, m$ denotes the share of domestic spending on home, imported or multinational products. Then:

(a) if $\alpha\left(\frac{\varepsilon-1}{\varepsilon}\right)\left(\frac{\mathrm{w}-1}{\mathrm{w}}\right)+\frac{\lambda}{\varepsilon} \geq \max \left\{\frac{\beta}{\varepsilon}, \frac{\tau}{\mathrm{p}_{\mathrm{f}}}\right\}$, then $\mathrm{G}$ is quasi-concave. If $\theta>1$ these conditions ensure that $G$ is increasing, while if $\theta<1$ then slightly stronger conditions are needed; ${ }^{14}$

(b) if $\alpha\left(\frac{\varepsilon-1}{\varepsilon}\right)\left(\frac{\mathrm{w}-1}{\mathrm{w}}\right)+\frac{\lambda}{\varepsilon} \leq \min \left\{\frac{\beta}{\varepsilon}, \frac{\tau}{\mathrm{p}_{\mathrm{f}}}\right\}$, then $\mathrm{G}$ is quasi-convex. 14 When $\theta<1$ we need to multiply the right-hand side of the inequality in (a) by $(\varepsilon-\theta) /(\varepsilon-1)>1$. Then for $\mathrm{s}_{\mathrm{m}}$
sufficiently small, $\mathrm{G}$ will be increasing. 
In (12), we show that $\partial \mathrm{G} / \partial \mathrm{m}$ consists of three terms. The first involves $\mathrm{s}_{\mathrm{h}}$, the share of home firms in domestic spending, and reflects the product market competition between the multinationals and the home firms: if $\beta \mathrm{s}_{\mathrm{h}}$ is high as compared to $\alpha$, then this term is negative. The second term reflects the loss in import revenue as multinationals enter, as first analyzed by Brecher and Diaz-Alejandro (1977). The third term reflects the wage premium generated by employment in the multinationals and the profit tax levied on these firms, both of which generate a gain in welfare.

Part (a) identifies conditions under which $\mathrm{G}$ is an increasing and quasi-concave function of m, as illustrated in Figure 2 on the curve labeled "High wage premium or taxes." It is well known from Brecher and Diaz-Alejandro (1977) that when foreign capital is taxed at a sufficiently high rate, this can reverse the decline in welfare that otherwise occurs from their entry. Our model adds the gain due to the wage premium paid by multinationals. Conversely, if the wage premium and taxes are low as in part (b), then $G$ is instead a quasi-convex function of $\mathrm{m}$, as indicated by the curve labeled "Low wage premium and taxes." In this case, it is relatively easy to choose the value of $\beta$ or of the tariff $\tau$ such that $\partial \mathrm{G} / \partial \mathrm{m}=0$ in (12). Such a critical point will be a global minimum of $\mathrm{G}$, as illustrated. ${ }^{15}$

While Proposition 1 gives us the properties of $\mathrm{G}$ with respect to $\mathrm{m}$, we do not suppose that the government directly controls entry of multinationals. Instead, entry is influenced through the tax rate $\lambda$ and the tariff rate $\tau$, so the number of multinational firms is written as a function $\mathrm{m}(\lambda, \tau)$. Multinationals react in the expected manner to changes in these policies:

\footnotetext{
${ }^{15}$ A convex curve between home welfare and the inflow of foreign capital was illustrated by Brecher and DiazAlejandro (1977, Figure 2), when foreign capital was not being taxes. In their model, there was no wage premium.
} 


\section{$\underline{\text { Lemma } 2}$}

When (9) holds as an equality, then $\frac{\mathrm{dm}}{\mathrm{d} \lambda}<0$ and $\frac{\mathrm{dm}}{\mathrm{d} \tau}>0$.

We are now in a position to setup and solve the governments' problem. We suppose that the central and the regional governments jointly determine the rents appropriated from the multinationals in each region. The central government also chooses the tariff rate. Denoting regions by the subscript $\mathrm{i}$, we let $\mathrm{G}_{\mathrm{i}}\left[\mathrm{m}_{\mathrm{i}}\left(\lambda_{\mathrm{i}}, \tau\right), \lambda_{\mathrm{i}}, \tau\right]$ denote the objective function for each region. Then the profit tax and tariff are chosen to solve:

$$
\max _{i}, \tau=\sum_{i} \mathrm{G}_{\mathrm{i}}\left[\mathrm{m}_{\mathrm{i}}\left(\lambda_{\mathrm{i}}, \tau\right), \lambda_{\mathrm{i}}, \tau\right]
$$

subject to $m_{i}\left(\lambda_{i}, \tau\right) \leq n_{f}$, which is the maximum number of foreign firms willing to enter any region. Our strong assumption in writing the objective function as in (13) is that the tax rate $\lambda_{\mathrm{i}}$ for one region is separable from that in another region. This is an extreme version of Young's (1997) thesis that the provinces in China have only limited trade with each other. If there is no trade between provinces, then they will not be in competition with one another for foreign investment, because multinationals can only serve the market where they locate. While this case does not literally apply in China, it is certainly true that foreign firm face restrictions on their ability to market outside their immediate area. ${ }^{16}$ By assuming an extreme form of these restrictions, we greatly simplify the governmental decision problem.

\footnotetext{
16 Some "native" Chinese firms face these restrictions as well. In interviews, one Chinese executive ruefully noted that while the government has been bringing in "multinational" enterprises for twenty years, few truly "multiprovincial" enterprises are allowed to operate within China itself!
} 
We also denote all other variables in region i with that subscript, though for simplicity we suppose this does not apply to the foreign price $\mathrm{p}_{\mathrm{f}}$, or the number of foreign firms $\mathrm{n}_{\mathrm{f}}$. The

following result describes the solution to (13) over the choice of the tax rate $\lambda_{i}$, while a discussion of the solution for tariffs $\tau$ is postponed until section 7 .

\section{Proposition 1}

Suppose that $\mathrm{G}_{\mathrm{i}}$ is increasing in $\mathrm{m}_{\mathrm{i}}$. Then region $\mathrm{i}$ will choose the tax rate $\lambda_{\mathrm{i}}$ to allow entry of multinationals to the point where either $\mathrm{m}_{\mathrm{i}}=\mathrm{n}_{\mathrm{f}}$ or,

$$
\frac{\partial \mathrm{G}_{\mathrm{i}}}{\partial \mathrm{m}_{\mathrm{i}}}=-\mathrm{m}_{\mathrm{i}} \pi_{\mathrm{mi}} / \frac{\partial \mathrm{m}_{\mathrm{i}}}{\partial \lambda_{\mathrm{i}}}=\frac{1}{\varepsilon}\left(\frac{\varepsilon-\theta}{\varepsilon-1}\right)\left(\mathrm{p}_{\mathrm{mi}} \mathrm{x}_{\mathrm{mi}}-\mathrm{p}_{\mathrm{f}} \mathrm{x}_{\mathrm{f}}\right)\left[\left(1-\lambda_{\mathrm{i}}\right) \mathrm{s}_{\mathrm{mi}}-\left(\frac{\mathrm{m}_{\mathrm{i}}}{\mathrm{n}_{\mathrm{f}}-\mathrm{m}_{\mathrm{i}}}\right) \mathrm{s}_{\mathrm{fi}}\right] .
$$

A point satisfying (14) is a global maximum of $G_{i}$ over the choice of $\lambda_{i}$ provided that

$$
\alpha\left(\frac{\varepsilon-1}{\varepsilon}\right)\left(\frac{\mathrm{w}_{\mathrm{i}}-1}{\mathrm{w}_{\mathrm{i}}}\right)+\frac{\lambda}{\varepsilon} \geq \max \left\{\frac{\beta}{\varepsilon}, \frac{\tau}{\mathrm{p}_{\mathrm{f}}}\right\} \text {, and also that } \mathrm{s}_{\mathrm{mi}} \leq(\varepsilon-1) /(\varepsilon-\theta) \text { when (14) holds. }
$$

The optimality condition (14) is illustrated at point A in Figure 2, where the slope of the curve $G_{i}$ equals $-m_{i} \pi_{m i} /\left(\partial m_{i} / \partial \lambda_{i}\right)$. This magnitude reflects the fall in the revenue $\lambda_{i} m_{i} \pi_{m i}$ when the tax rate is lowered to attract more multinationals. That is, the regions are acting as monopsonists as they attract foreign capital. This can be contrasted with the competition for foreign capital that is often modeled between industrial countries or regions, and that is ruled out in our framework by the assumption of limited trade between the regions. 
Condition (14) leads to a global optimum under the conditions of Lemma1(a), and also $\mathrm{s}_{\mathrm{mi}} \leq(\varepsilon-1) /(\varepsilon-\theta)$, which is automatically satisfied when $\theta>1$ so that $(\varepsilon-1) /(\varepsilon-\theta)>1$. If instead the conditions of Lemma1(b) hold, so that $\mathrm{G}_{\mathrm{i}}$ is quasi-convex in $\mathrm{m}_{\mathrm{i}}$, then it is still possible for the problem (13) to have an interior maximum: the fact that the regions are acting as monopsonists, and recognize that multinational entry is affected by the profit tax, leads to further concavity in $\mathrm{G}_{\mathrm{i}}\left[\mathrm{m}_{\mathrm{i}}\left(\lambda_{\mathrm{i}}, \tau\right), \lambda_{\mathrm{i}}, \tau\right]$ as a function of $\lambda_{\mathrm{i}}$. In our estimation, we will confirm that the second-order conditions are in fact satisfied.

We can now use the results from Proposition 1 to develop an estimating equation. We add the subscript $\mathrm{i}$ to the variables in (12), and replace $\mathrm{s}_{\mathrm{mi}}$ with $1-\mathrm{s}_{\mathrm{hi}} \mathrm{s}_{\mathrm{fi}}$ on the right-hand side. This is set equal to the right-hand side of (14), as required for optimality. The resulting equation can be simplified by using (9) as an equality. Finally, we also add a time subscript to all relevant variables. We obtain the following equation for the share of spending on products of multinationals in region $\mathrm{i}$ and year $\mathrm{t}$ :

$$
\begin{aligned}
& \mathrm{s}_{\text {mit }}=-\beta \mathrm{s}_{\text {hit }}+\eta\left(\frac{\mathrm{w}_{\mathrm{it}}-1}{\mathrm{w}_{\mathrm{it}}}\right)+\alpha(\varepsilon-1)\left(\frac{\mathrm{w}_{\mathrm{it}}-1}{\mathrm{w}_{\mathrm{it}}}\right)\left(\mathrm{s}_{\text {hit }}+\mathrm{s}_{\mathrm{fit}}\right)-\varepsilon\left(\frac{\tau_{\mathrm{t}}}{\mathrm{p}_{\mathrm{ft}}}\right) \mathrm{s}_{\mathrm{fit}}+\left(\frac{\mathrm{m}_{\mathrm{it}}}{\mathrm{n}_{\mathrm{f}}-\mathrm{m}_{\mathrm{it}}}\right) \mathrm{s}_{\mathrm{fit}} \\
& \quad+\frac{\alpha \varepsilon}{(\varepsilon-\theta)}+\left\{\frac{(\varepsilon-1) \lambda_{\text {it }} \pi_{\text {mit }}}{(\varepsilon-\theta)\left(\mathrm{F}_{\mathrm{it}}+\lambda_{\mathrm{it}} \pi_{\mathrm{mit}}\right)}+\left[\frac{\alpha(\varepsilon-1)^{2}}{(\varepsilon-\theta)}\left(\frac{\mathrm{w}_{\mathrm{it}}-1}{\mathrm{w}_{\mathrm{it}}}\right)-\varepsilon\left(\frac{\tau_{\mathrm{t}}}{\mathrm{p}_{\mathrm{ft}}}\right)\right] \frac{\pi_{\mathrm{ft}}}{\left(\mathrm{F}_{\mathrm{it}}+\lambda_{\mathrm{it}} \pi_{\mathrm{mit}}\right)}\right\}
\end{aligned}
$$

The first term on the right-side of (15) is the share of spending on domestic state-owned firms, which enters with the coefficient $-\beta$. Thus, the weight on state-owned firms in the regional objective function is simply obtained as the coefficient on their share in the regression (15). A 
high weight on the state-owned firms indicates that in regions where these firms are more prevalent, the share of multinational firms will be correspondingly reduced.

The next term on the right of (15) is the wage premium paid by multinationals, which has the coefficient $\eta \equiv \alpha(\varepsilon-1)(\theta-1) /(\varepsilon-\theta)$. Following this is the wage premium times the share of spending on state-owned firms plus imports. When the wage premium is higher, we expect that regions would be more willing to accept multinationals, and this is confirmed by having a positive coefficient $\alpha(\varepsilon-1)$ on that variable. The estimate of $\varepsilon$ itself comes from the next term, which is the ad valorem tariff rate times the share of spending on imports. This term reflects the loss in tariff revenue as multinationals enter, and the coefficient is $-\varepsilon$. Thus, combined with the former coefficient we can recover an estimate of $\alpha$. The final term on the first line of (15) reflects the number of multinationals times the share of imports. For simplicity we treat $\mathrm{n}_{\mathrm{f}}$, which is the number of foreign firms wanting to export or invest in China, as constant over regions and time, and estimate it as a coefficient.

The terms on the second line of (15) are rather complex expressions of the profit tax collected in each region, and the fixed costs of entry, entering themselves and interacted with the wage premium and tariffs. We have no way of measuring these terms, but it seems very likely that they will vary systematically across regions, and possibly also over time. Thus, we will model the terms on the second line of (15) as:

$$
\left\{\frac{(\varepsilon-1) \lambda_{\mathrm{it}} \pi_{\mathrm{mit}}}{(\varepsilon-\theta)\left(\mathrm{F}_{\mathrm{it}}+\lambda_{\mathrm{it}} \pi_{\mathrm{mit}}\right)}+\left[\frac{\alpha(\varepsilon-1)^{2}}{(\varepsilon-\theta)}\left(\frac{\mathrm{w}_{\mathrm{it}}-1}{\mathrm{w}_{\mathrm{it}}}\right)-\varepsilon\left(\frac{\tau_{\mathrm{t}}}{\mathrm{p}_{\mathrm{ft}}}\right)\right] \frac{\pi_{\mathrm{ft}}}{\left(\mathrm{F}_{\mathrm{it}}+\lambda_{\mathrm{it}} \pi_{\mathrm{mit}}\right)}\right\}=\gamma_{\mathrm{i}}+\delta_{\mathrm{t}}+\mathrm{u}_{\mathrm{it}},
$$

where $\gamma_{i}$ and $\delta_{t}$ and province and year fixed-effects, and $u_{i t}$ is a random error assumed to be uncorrelated with the variables on the first line of (15). Gathering all these terms into fixed- 
effects plus an error is a strong assumption, but we have no other way of dealing with them. With this assumption, we will be able to estimate (15) with two-stage least squares applied to panel data.

Before turning to a discussion of the data, we remind the reader that we have assumed that a multinational's entry into one region will not affect its willingness to enter another region. We could weaken this assumption somewhat by instead writing the constraint as $\Sigma_{\mathrm{i}} \mathrm{m}_{\mathrm{i}}\left(\lambda_{\mathrm{i}}, \tau\right) \leq \mathrm{n}_{\mathrm{f}}$. In that way, regions are competing for a fixed stock of foreign multinationals. If this constraint is binding, it means that we would need to add a Lagrange multiplier onto the right of (14). This multiplier would be time-dependent, and would also appear on the right of (15). But since it would appear as a yearly fixed effect in (16), then the estimating equation is not affected.

A more significant change would be to consider instances where multinational entry is not allowed, perhaps because $\mathrm{G}_{\mathrm{i}}$ is declining in $\mathrm{m}_{\mathrm{i}} \cdot{ }^{17}$ These observations can be incorporated into (15) by allowing the dependent variable to be zero, in which case the value of the right-hand side should be negative. In other words, zero multinational presence can in principle be incorporated into our estimation if we allow for a Tobit estimation. This raises technical difficulties, however, because we also have fixed-effects as in (16), and some of the right-hand side variables are endogenous (as discussed below). To date, there is no available estimator for a censored model with fixed effects and endogenous variables. For this reason, we restrict the dependent variable in (15) to positive values. ${ }^{18}$

\footnotetext{
${ }^{17}$ If the weight on state-owned firms $\beta$ is sufficiently large, for example, then $\mathrm{G}_{\mathrm{i}}$ can be declining in $\mathrm{m}_{\mathrm{i}}$ even when multinationals are taxed at a high rate.

18 A further difficulty with incorporating zero values for the dependent variable (i.e. when multinationals are not present in a province), is that some of the right-hand side variables are then not available. In particular, the wagepremium paid by multinationals, which appears on the right of (15) directly and as an interaction term, cannot be measured when there is no such activity in the province.
} 


\section{Data and Estimation Issues}

We have three sources of data, described in increasing order of reliability. The first is a collection of data from the provincial yearbooks for 1978-1995 (Xinjiang Statistical Bureau, 1998). There are 30 provinces or autonomous regions distinguished in this source, and we will refer to it henceforth as the "regional data." This provides data on FDI, employment, wages, and output, with the latter broken down by state-owned firms, multinationals, collectives, and individual proprietorships. ${ }^{19}$ The wage data does not begin until 1984, effectively limiting our sample to 1984-1995. It distinguishes the wages paid per worker in multinationals, state-owned enterprises, and urban collectives, with that in multinationals usually being the highest and that in urban collectives usually the lowest. ${ }^{20}$ The wage premium was constructed in two ways. The first method (called unweighted) was to compute it as the wages paid by multinationals minus that in urban collectives, divided by that in multinationals. The second, possibly more accurate method (called weighted), was to compute the wage premium as the wages paid by multinationals minus a weighted sum of the wages paid in state-owned enterprises and urban collectives, using employment shares (from the regional data) as weights, with this difference divided by the multinational wage.

The second data source was various editions of the Chinese Statistical Yearbooks, which we judge to be more reliable than the provincial yearbooks. In the case of discrepancies, the provincial output data for state-owned firms, multinationals, collectives, and individual

19 In early years, there is no category exclusively for multinational (or foreign invested enterprises). Rather, there is a category of output attributed to "other" firms, which includes both multinationals and other stock-held companies. In later years, it was possible to separate out the stock-held companies from the multinationals using data provided. In early years this was not possible, except that we did restrict the output share of multinationals to be zero until another series for "foreign capital actually invested" became positive.

20 As in the previous footnote, in early years there is no category exclusively for multinational wages, but there is "other" wages that includes both multinationals and other stock-held companies. In later years, we could compare this "other" category with actual wages paid by multinationals, and found that they followed each other very closely. The correlation coefficient between the two series was 0.905 . 
proprietorships have been replaced with the corresponding figures from the Statistical Yearbooks, when the latter had this data. In a limited number of cases for 1984-1985, provincial output data for state-owned firms, multinationals, collectives, or individual proprietorships had to be imputed based on employment in these categories.

The third data source was the Chinese trade data obtained from the Customs General Administration as part of the project described in Feenstra, Hai, Woo and Yao $(1998,1999) .{ }^{21}$ This source gives imports and exports broken down by Chinese province, the kind of Chinese enterprise involved in the trade (state-owned enterprise, foreign-invested enterprise, other), and the type of trade regime under which the transaction took place (ordinary trade, processing trade, other), for 1988-1995. We judge this to be our most reliable data source, and use it to correct the trade data from the provincial yearbooks, as described below.

Two methods are used to measure the share variables. In the first, we simply take the output of state-owned firms and multinationals, or the spending on imports, and measure this relative to nominal output plus imports, for 1984-1995:

Method A: $\quad s_{j i t}= \begin{cases}\frac{\text { Output }_{j}}{\text { Total Output }+ \text { Imports }} & \text { for } j=h, m, \\ \frac{\text { Imports }}{\text { TotalOutput }+ \text { Imports }} & \text { for } j=f .\end{cases}$

The problem with this method is that it does not correct for the fact that the output of both stateowned firms and multinationals is exported. In our theory we are focusing on domestic productmarket competition between these firms, and so exports should be netted out. This is especially true since a good deal of output, especially for multinationals, is for processing exports, which 
means that intermediate inputs are imported, had some value-added, and then exported again. The use of nominal output will greatly overstate the actual value-added in these activities. By the same token, the use of nominal imports in the Method A will greatly overstate the imports that are not intended for processing, and potentially compete with state-owned firms.

To correct Method A for both exports and processing imports, we make use of the Chinese trade data obtained from the Customs General Administration. This allows us to measure the exports by type of firm (state-owned and multinational), and also to measure “ordinary" imports, that are not intended for processing, by province and year for 1988-1995. The shares of domestic spending are then measured as:

Method B: $\quad s_{j i t}=\left\{\begin{array}{cl}\frac{\text { Output }_{j}-\text { Exports }_{j}}{\text { Total Output }- \text { Exports }+ \text { Ordinary Imports }} & \text { for } \mathrm{j}=\mathrm{h}, \mathrm{m}, \\ \frac{\text { Ordinary Imports }}{\text { TotalOutput -Exports + Ordinary Imports }} & \text { for } \mathrm{j}=\mathrm{f} .\end{array}\right.$

We expect that Method B gives more accurate shares than in Method A, but for the shorter time period 1988-1995. Thus, when estimating over the entire period 1984-1995, we either use Method A alone, or Method A for 1984-1987 combined with Method B for 1988-1995.

These alternative treatments of the share variables combine with our two alternative methods for computing the wage premium (weighted versus unweighted) to give us four alternative treatments of the data. Each of these four variations represent a slightly different compromise in terms of testing our theory against admittedly imperfect data. For completeness and for purposes of comparison, we will present results from all four variants.

21 We acknowledge the support of the Harvard Institute of International Development, and the Customs General Administration, People's Republic of China, in providing the data for that study. 
Estimation of (15) requires that we correct for endogeneity of the regressors. This occurs because the dependent variable and some independent variables are shares of domestic spending, and in our theory sum to unity: $\mathrm{s}_{\mathrm{mit}}+\mathrm{s}_{\mathrm{hit}}+\mathrm{s}_{\mathrm{fit}}=1$. Thus, the share of spending on multinational output $\mathrm{s}_{\text {mit }}$ (which appears on the left of 15), and the share of spending on state-owned firms shit (which appears on the right), would tend to have a correlation of -1 by construction. We correct for this in several ways. When we measure the share of spending on multinationals, state-owned firms, and imports, we include the spending on products from collectives and individual proprietorships. ${ }^{22}$ This means that the shares $\mathrm{s}_{\mathrm{mi}}, \mathrm{s}_{\mathrm{hi}}$, and $\mathrm{s}_{\mathrm{fit}}$ sum to less than unity.

Furthermore, we include the spending on collectives and individual proprietorships as control variables on the right of (15). For example, a reduction in spending on products from collectives will increase all of $\mathrm{s}_{\text {mit, }} \mathrm{s}_{\text {hit, }}$ and $\mathrm{s}_{\mathrm{fit}}$, which would tend to create a positive correlation between $\mathrm{s}_{\mathrm{mit}}$ and $\mathrm{s}_{\mathrm{hit}}$ in (15); including the spending on collectives and individual proprietorships as controls offsets this bias. Finally, we use instrumental variables when estimating $(15) .^{23}$

A selection of the data for 1995 is shown in Table 1. For convenience, we report the data according to three regional groupings: Beijing and the neighboring industrial province of Tianjin; all those provinces that are coastal, and contain at least one "open coastal city" or SEZ; and then the interior provinces. For the coastal provinces, the ordering runs north to south; while for the interior provinces, the order runs roughly clockwise from north to south, and then circling around to the far inland provinces. It is readily apparent that some coastal provinces have a share of domestic spending on products of multinationals that equals or exceeds that for state-owned

22 That is, Total Output appearing in the denominator of (17) and (18) includes the output of collectives and individual proprietorships, as does Exports in (18).

${ }_{23}$ The instruments are the nominal sales of state-owned firms, value of imports, lagged FDI stock, output, wage premium, the interaction between the wage premium and these four variables, as well as the two control variables. 
enterprises; the average of these two shares is $14.4 \%$ and $20.2 \%$ respectively. $^{24}$ In contrast, the interior provinces have an average share of multinationals and state-owned enterprises of $3.5 \%$ and $55.1 \%$, respectively. This illustrates the much more limited multinational presence in the interior provinces, where the state plays a greater role.

Of course, this difference in the relative presence of multinationals versus state-owned firms in the coastal and interior provinces can be explained by the natural tendency of the multinationals to locate where transportation is easier, combined with the deliberate decision of Chinese planners to develop state-owned enterprises in the inland regions. In our estimation, we fully control for these differences by including fixed effects across provinces (and also fixed effects for each year). Thus, the identification of the political weights on stated-owned enterprises versus consumers will come from the time-series variation within each province, over 1984-1995, and not from the cross-sectional variation that is so apparent in Table 1.

Two other variables are also needed to estimate (15). As a proxy for the number of multinational firms $\mathrm{m}_{\mathrm{it}}$ in a province in a given year, we use the cumulated stock of foreign direct investment actually utilized (in billions of US\$). This was computed by taking flows of foreign direct investment from the regional data and cumulating them using a depreciation rate of $4.5 \% .^{25}$ The 1995 value for this variable was shown in Figure 1. It is interacted with the import share $\mathrm{s}_{\mathrm{fit}}$ on the right of (15), and the coefficient is then $1 /\left(\mathrm{n}_{\mathrm{f}}-\mathrm{m}_{\mathrm{it}}\right)$. For simplicity, we suppose

24 Note that for Guangdong, the "zero" share for state-owned enterprises in 1995 arises because the exports of these enterprises from the Chinese customs data exceeds their output from the provincial yearbooks or Chinese Statistical Yearbooks. This reflects a discrepancy between the two data sources, but we can still presume that the output of state-owned enterprises in Guangdong for domestic consumption is small.

25 This depreciation rate was based on data drawn from the 1994 Benchmark Survey on U.S. direct investment abroad conducted by the Bureau of Economic Analysis of the U.S. Department of Commerce. We are grateful to Michael Ferrantino of the International Trade Commission for drawing our attention to this document, and performing the computation that produced this number. However, we note that our results are not sensitive to the assumed rate of depreciation, and we obtain similar results with a depreciation rate of zero. 
that $\mathrm{n}_{\mathrm{f}}$ is large enough so that this coefficient can be treated as constant over time and regions, and re-write it as $1 / \mathrm{n}_{\mathrm{f}}$ when estimating (15).

Finally, the tariff variable is computed for province $\mathrm{i}$ in year $\mathrm{t}$ as a weighted average of $a d$ valorem tariffs, based on the provincial imports of different goods multiplied by the 1996 tariff rate assessed on those good. Unfortunately, we did not have access to any earlier years of tariff data. However, we were able to include in this calculation an indicator variable, equal to one when that product is also exported by FIEs in the province, and zero otherwise. Thus, the weights used to compute the average tariff were the provincial imports of different goods times the indicator variable, indicating whether the good was also exported (and therefore produced) by FIEs. This was done because the tariffs we are really interested are those on imported goods that potentially compete with local FIE-produced goods. Including this indicator variable ensures that only those imports which potentially compete with local FIE-produced goods are included in the weighted average tariff level. ${ }^{26}$ These average provincial tariff levels are shown in the last column of Table 1. Because this variable was constructed using the tariff schedule in only one year (1996), it actually varies across provinces i rather than years t. Thus, it is re-written as $\tau_{\mathrm{i}}$ rather than $\tau_{\mathrm{t}}$ in $(15)$.

\section{Estimation Results}

Results from regressions based on (15)-(16), using data for 1984-1995, are presented in Table 2. Each of the four columns uses a different variant of the wage premium and the share data. The overall results are broadly similar in all variants, although the exact parameter

\footnotetext{
${ }^{26}$ We do not have disaggregated data on FIE production, but we do have disaggregated data on FIE exports. Our presumption is that if FIEs are exporting a good from a Chinese province, then they are also probably selling some quantity of that good on the local market, or that at least the potential for local sales exists.
} 
estimates do vary. We also note that our key parameters are estimated with varying degrees of precision in these four columns. Standard errors are placed in parentheses below the respective parameter estimates.

Each regression includes a full set of provincial and year fixed effects. An estimate of the parameter $\beta$, the weight of state-owned enterprise output in the government's objective function, can be taken from the regression coefficient on the state-owned share. This coefficient is always statistically significant and, usually larger (in absolute value) than unity, though not significantly so. Estimates of $\alpha$, the weight on consumer welfare, can be derived from the regression coefficients shown in the third and fourth rows of Table 2. These estimates are reported in the first row of Table 3, where we also repeat the estimates of $\beta$ and $\varepsilon$. Despite some difference in the estimates over our four variations, a striking pattern emerges: we find that the weight applied to consumer welfare is much lower than that applied to the output of state-owned enterprises, with their ratio between one-fifth and one-twelfth in our estimates.

Turning to the other coefficients in Table 2, an estimate of $\theta$ can be derived from the coefficient on the wage premium. The point estimate for $\theta$ is always negative, which contradicts our assumption in (1), but a 95\% confidence interval constructed from the other coefficients includes both positive and negative values. Thus, our estimation fails to identify this parameter with any precision. The coefficient $1 / \mathrm{n}_{\mathrm{f}}$ takes the value $0.014-0.023$ in Method A, and inverting this, we estimate that there is $\$ 40-70$ billion of foreign capital ready to invest in any region of China. This parameter is estimated with the wrong sign in Method B, however.

We can make use of our parameter estimates to check that the second-order conditions for the maximization problem (13) are satisfied. Proposition 1 provides us with sufficient conditions that are easily checked, depending on the choice of $\lambda_{\mathrm{i}}$. However, given the tariffs 
reported in the last column of Table 1, and the parameter estimates in Table 3, these sufficient conditions are not satisfied even for very high choices of the profit tax $\lambda_{\mathrm{i}}$. Instead, we need to directly compute the second-derivative of $\mathrm{G}_{\mathrm{i}}\left[\mathrm{m}_{\mathrm{i}}\left(\lambda_{\mathrm{i}}, \tau\right), \lambda_{\mathrm{i}}, \tau\right]$ with respect to $\lambda_{\mathrm{i}}$, as done in the Appendix. This second-derivative is evaluated at the critical point (14). For the choice of parameters $\varepsilon=5, \theta=0.5, \beta=1, \alpha=0.2$ and $1 / \mathrm{n}_{\mathrm{f}}=0.02$, we find that the second order condition is satisfied for every province provided that $\lambda_{i} \geq 0.18$. Using higher values of the elasticities $\varepsilon=10$ and $\theta=2$, the second-order conditions are satisfied provided that $\lambda_{i} \geq 0.26$. These values are well within the range of actual tax rates in China (15\% in the SEZ and $24 \%$ in the open coastal cities), without even including the many other ways that rents are extracted from multinationals. We conclude, therefore, that our objective function is "well behaved."

The use of instrumental variables raises the question of the validity of the instruments. To assess this, we regress the residuals from the estimated equations on the instruments, and report in Table 2 the $\chi^{2}$ statistic constructed as $\mathrm{NR}^{2}$ from this regression. We note that this approach has been criticized in the econometrics literature for a tendency to "over-reject" the null hypothesis of validity of the over-identifying restrictions. Indeed, in one of our four regressions, the null hypothesis of validity is rejected at the $5 \%$ level, as the $\chi^{2}$ test statistic is (slightly) larger than the critical value of 9.49. Otherwise, the null hypothesis is easily accepted at conventional levels.

A breakdown of the implied structural coefficients of interest is provided in Table 3 for later sub-samples of the data, the 1988-1995 period and the 1990-1995 period. As we confine our view to the later sub-samples, we lose observations and consequently precision in some of our estimates; sub-periods smaller than 1990-1995 do not yield many significant coefficients at 
all. In the later sub-periods, the estimated magnitudes of the weight on state-owned enterprises falls. Likewise the weight on consumer welfare rises. This is consistent with the historical trend towards liberalization, of course. However, the gap between the two weights remains substantial: for the relatively liberal 1990-95 sub-period, we find that the weight on consumer welfare is still only about one-half of the weight on state-owned enterprises. This is consistent with the pessimism among some China scholars concerning the momentum of reform of restrictions on FDI and trade.

\section{Choosing the Tariffs}

At the beginning of the paper, we motivated our topic by the desire of China to enter into the WTO, and suggested that the existing trade barriers would have to be reduced substantially to achieve this goal. To what extent does the presence of multinationals interact with that goal? The willingness of foreign firms to invest in China certainly reflects, in part, the difficulty of importing there directly. If tariffs are reduced substantially, this raises the distinct possibility that foreign firms who are not just involved in processing trade will divest of some of their holdings. This scenario was explicitly mentioned in some of our field interviews, and reflects the fact that for firms not involved in processing trade, investment in China is an attempt to access the huge domestic market; low wages play only a secondary role.

If we accept this characterization of foreign direct investment, it suggests that a reduction in tariffs may lead to an outflow of foreign direct investment. There is no "natural experiment" that allows us to directly estimate this from data for China. However, we can use the estimates from the previous section to construct the outflow that is consistent with our theoretical model, in an attempt to judge the welfare impact. 
To compute the welfare effects, we begin by characterizing the optimal tariff in a special case. Suppose that the government does not care about state-owned profits $(\beta=0)$, there are no multinationals $\left(\mathrm{m}_{\mathrm{i}}=0\right)$, and the tariff is applied to a single import variety . Then it can be shown that in this simple case, the optimal tariff which maximizes (13) is:

$$
\frac{\tau *}{p_{\mathrm{f}}}=\frac{1}{\varepsilon}-\left(\frac{\alpha}{\varepsilon-1}\right)
$$

To interpret this condition, suppose that $\alpha=0$ so the government did not care about consumer welfare. Then $\tau^{*} / \mathrm{p}_{\mathrm{f}}=1 / \varepsilon$ is the revenue maximizing tariff. As $\alpha>0$ then the optimal tariff is reduced below this level. ${ }^{27}$

Now consider the total effects of a change in tariff on welfare, given that $\beta, \mathrm{m}_{\mathrm{i}}>0$ and the multinational profit tax $\lambda_{i}^{*}$ has been chosen optimally. We compute the change in the objective function of a single region $\mathrm{G}_{\mathrm{i}}\left[\mathrm{m}_{\mathrm{i}}\left(\lambda_{\mathrm{i}}^{*}, \tau\right), \lambda_{\mathrm{i}}^{*}, \tau\right]$ as:

$$
\begin{aligned}
\frac{\mathrm{dG}_{\mathrm{i}}}{\mathrm{d} \tau} & =\frac{\partial \mathrm{G}_{\mathrm{i}}}{\partial \tau}+\frac{\partial \mathrm{G}_{\mathrm{i}}}{\partial \mathrm{m}_{\mathrm{i}}} \frac{\partial \mathrm{m}_{\mathrm{i}}}{\partial \tau} \\
& =\frac{\partial \mathrm{G}_{\mathrm{i}}}{\partial \tau}-\mathrm{m}_{\mathrm{i}} \pi_{\mathrm{mi}} \frac{\partial \mathrm{m}_{\mathrm{i}}}{\partial \tau} / \frac{\partial \mathrm{m}_{\mathrm{i}}}{\partial \lambda_{\mathrm{i}}} \\
& =\frac{\partial \mathrm{G}_{\mathrm{i}}}{\partial \tau}+\left.\mathrm{m}_{\mathrm{i}} \pi_{\mathrm{mi}} \frac{\mathrm{d} \lambda_{\mathrm{i}}}{\mathrm{d} \tau}\right|_{\mathrm{m}_{\mathrm{i}}} .
\end{aligned}
$$

\footnotetext{
${ }^{27}$ Note that if $\alpha=1$ so that consumer welfare and revenue receive the same weights, then the optimal tariff is negative. The reason for this is that with a specific tariff and constant percentage markup (due to CES preferences), then the "terms of trade effect" is negative: raising marginal costs using the tariff leads to an even greater increase in import prices, implying that the net-of-tariff price goes up instead of down. It follows that an import subsidy is optimal. For the range of $\alpha<1$ in our estimates, however, we certainly obtain a positive value for the optimal tariff $\tau^{*}$ in (19), due to its revenue impact.
} 
The first line of (20) uses the envelope theorem, whereby we can hold $\lambda_{i}^{*}$ constant when computing the effect on $\mathrm{G}_{\mathrm{i}}$ of changing $\tau$. The second line makes use of the first-order condition (14), and then the third line follows by computing $d \lambda_{i} /\left.d \tau\right|_{m_{i}}>0$ as the slope of an iso-curve of $\mathrm{m}_{\mathrm{i}}\left(\lambda_{\mathrm{i}}, \tau\right)$. Thus, the total impact of decreasing tariffs can be interpreted as: (i) the direct impact holding the profit tax and number of multinationals fixed; and (ii) the indirect effect through decreasing the profit tax itself so that multinationals do not exit the country.

Given this interpretation, we now compute each of the components (i) and (ii) from our model. Because the tariff is specific, it useful to measure it relative to foreign prices $\mathrm{p}_{\mathrm{f}}$, and we also measure the regional objective function relative to total imports if the differentiated good, denoted by $\mathrm{M}_{\mathrm{i}} \equiv\left(\mathrm{n}_{\mathrm{f}}-\mathrm{m}_{\mathrm{i}}\right) \mathrm{p}_{\mathrm{fi}} \mathrm{x}_{\mathrm{fi}}$ :

\section{Proposition 2}

The total impact on a region's objective function from changing tariffs is given by (20), where:

$$
\begin{aligned}
& \frac{\mathrm{p}_{\mathrm{f}}}{\mathrm{M}_{\mathrm{i}}} \frac{\partial \mathrm{G}_{\mathrm{i}}}{\partial \tau}=\varepsilon\left[\frac{\tau *}{\mathrm{p}_{\mathrm{f}}}-\frac{\tau}{\mathrm{p}_{\mathrm{f}}}\left(1-\left(\frac{\varepsilon-\theta}{\varepsilon-1}\right) \mathrm{s}_{\mathrm{fi}}\right)\right]+\left(\frac{\varepsilon-\theta}{\varepsilon-1}\right)\left\{\beta \mathrm{s}_{\mathrm{hi}}+\left[\lambda_{\mathrm{i}}+\frac{\alpha\left(\mathrm{w}_{\mathrm{i}}-1\right)(\varepsilon-1)}{\mathrm{w}_{\mathrm{i}}}\right] \mathrm{s}_{\mathrm{mi}}\right\} \\
& \text { and, }\left.\quad \mathrm{m}_{\mathrm{i}} \pi_{\mathrm{mi}} \frac{\mathrm{p}_{\mathrm{f}}}{\mathrm{M}_{\mathrm{i}}} \frac{\mathrm{d} \lambda_{\mathrm{i}}}{\mathrm{d} \tau}\right|_{\mathrm{m}_{\mathrm{i}}}=\left(\frac{\varepsilon-\theta}{\varepsilon-1}\right)\left\{\left(1-\lambda_{\mathrm{i}}\right) \mathrm{s}_{\mathrm{mi}}-\left(\frac{\mathrm{m}_{\mathrm{i}}}{\mathrm{n}_{\mathrm{f}}-\mathrm{m}_{\mathrm{i}}}\right) \mathrm{s}_{\mathrm{fi}}\right\}+\left(\frac{\mathrm{m}_{\mathrm{i}}}{\mathrm{n}_{\mathrm{f}}-\mathrm{m}_{\mathrm{i}}}\right) .
\end{aligned}
$$

Expression (21) gives the change in welfare due to a change in the tariff, holding the number of multinationals constant. This expression is larger when there is greater political 
weight on state-owned enterprises, or wage premia paid by multinationals: these considerations mean that increases in the tariff above the "simple" optimum in (19) will raise welfare, whereas tariff reductions potentially lower welfare. Expression (22) takes into account the induced effects of tariff changes on the profit tax obtained from multinationals. Since this expression is positive, is leads to a welfare loss from any tariff reduction.

The unweighted average of the 1996 tariffs in China is 23.4\%, and under its WTO accession proposal the tariffs in 2005 would be reduced to $16.2 \%$, or three-quarters of their 1996 value. ${ }^{28}$ Applying this reduction to the 1996 tariffs used in our estimation (the last column of Table 1), we obtain the proposed WTO tariffs shown in the first column of Table 4, at the provincial level. Then using this change of tariff from their 1996 level to the WTO proposal, we evaluate the welfare impact from Proposition 2, with results shown in Table 4.

In the first example of Table 4 , we use low values of the elasticities: $\varepsilon=5$ and $\theta=0.5$. We also use the weight on consumer welfare of $\alpha=0.2$, a weight on state-owned firms of $\beta=1$, and a value of $1 / \mathrm{n}_{\mathrm{f}}=0.02$, which are consistent with our earlier estimates. The "simple" optimal tariff in (19) for these parameters is $\tau * / \mathrm{p}_{\mathrm{f}}=0.15$. The direct effect of lowering the tariffs is computed from (21), and the indirect effect through lowering the profit tax for multinationals is computed from (22). ${ }^{29}$ We see that the direct welfare effect varies in sign over the provinces. Beijing has a direct welfare benefit of $2 \%$ of its import value, reflecting its rather high initial tariff $(41 \%$ in Table 1), whereas Liaoning has a direct welfare loss because its initial tariff (23\%) is less than the provincial optimum, taking into account the weight given to state-owned firms and wage

28 These unweighted tariffs are reported in World Bank (1997, Annex Table A.1). If we take the longer period from 1992 to 2005, then unweighted tariffs are reduced by one-half. Thus, to evaluate this total change, the welfare effects in Table 4 should all be doubled. 
premia. However, the indirect impact of lowering the profit tax for multinationals means that the gains to Beijing from tariff reduction are more than offset, and the total impact of tariff reduction becomes negative. This reversal of the direct gains, leading to overall losses, is also found for the neighboring industrial region of Tainjin, and nearly so for Fujian. These regions illustrate the idea that the losses through potential departure of multinationals can offset the direct gains from tariff reduction, making such liberalization politically difficult to achieve. This is reinforced by the negative direct effect of tariff reductions found for quite a number of other provinces.

In the second example we consider higher elasticities: $\varepsilon=10$ and $\theta=2$. Higher values for either of these elasticities make it more likely that welfare gains will be found from tariff reduction. Other parameters are as before $(\alpha=0.2$ and $\beta=1)$, so the "simple" optimal tariff in (19) is now $\tau * / \mathrm{p}_{\mathrm{f}}=0.078$. We find that nearly all regions now have direct gains from tariff removal, which are substantially larger than the indirect losses. For example, Beijing has a direct gain of $20.4 \%$ of its import value, which is much larger than the $2 \%$ indirect loss due to potential exit of multinationals. Gains of a smaller magnitude are observed for most other provinces. Thus, with high values for the elasticities, most provinces gain from the proposed reduction of tariffs under China's WTO proposals, but for low values of the elasticities this is not the case. Both these cases are within the range of elasticities (for $\varepsilon$ ) that we have estimated. So while we are not able to make more definite conclusions about the potential losses due to multinational exit, and whether these offset the gains due to tariff removal, this possibility is certainly within the range of our estimates.

\footnotetext{
29 Note that both (21) and (22) depend on $\lambda$, but that this term enters in an exactly offsetting way in each expression. Thus, the total effect does not depend on value specified for $\lambda$, so we exclude this term from the calculation of (21) and (22) individually.
} 


\section{Conclusions}

After two decades of substantial reform, China's current trade and foreign investment regime remains far from open. If ever we needed a theoretical framework to explain sharp deviations of policy away from that proscribed by laissez faire economics, we need it here. Our paper represents a first attempt to apply a theoretical model based on Grossman and Helpman $(1994,1996)$ to a policy context in which "political economy" considerations are essential for understanding and predicting the trajectory of economic reform, and then to obtain economically meaningful estimates of the model's parameters from Chinese economic data.

As in any ambitious attempt to marry a complicated structural model with imperfect data, we have been driven to make a number of compromises. Nevertheless, the results that we end with are quite striking. To summarize, using the estimates based on our full sample, we find that the weight applied to consumer welfare is between one-fifth and one-twelfth of the weight applied to the output of state-owned enterprises. We find that governmental preferences have shifted over time, but even if we estimate the model with data from the relatively liberal 1990-95 sub-period we still find that the weight on consumer welfare is only about one-half of the weight on state-owned enterprises. Finally, we estimate the impact on regional governmental objectives of the proposed changes in tariff structure that China has put forth as part of its bid for WTO accession. We find that these changes could potentially lower the regional objective function, due to the exit of multinationals. While this result is sensitive to the elasticities that are used, it provides some quantitative backing for skepticism that China, given the current political equilibrium, would actually follow through with the proposed liberalization.

There are a number of directions in which we hope to move this research in future papers. Most will involve more disaggregated data on multinational and state-owned production and 
trade. It is obvious that government and other barriers differ in systematic ways across industries, and part of the provincial variance that we are picking up in our data is really attributable to differences across provinces in industry mix. Anecdotal evidence also suggests that there are important differences in the nature of multinationals depending on the "source country." In particular, firms are affiliated with Taiwanese or Hong Kong-based foreign partners are overwhelmingly concentrated on production for export, and hence are to a great extent outside our modeling framework. With more disaggregated data, we could focus on the Western and Japan-affiliated multinationals that tend to be more focused on the Chinese market, and therefore more relevant for our model. To this end, we are currently building up an FDI data base at the project level.

Further refinements in the model might also prove worthwhile. While a more realistic depiction of the actual restrictions placed on multinationals (such as local content and export requirements) would complicate the model, it would also likely yield much more accurate estimates of the real relative weight placed on consumer welfare. If anything, our current estimates may prove to be an upper bound of the weight actually placed on consumer welfare by the Chinese government. 


\section{Appendix}

For notational ease, denote the numbers of home firms, importing firms, and

multinational firms by $\mathrm{n}_{\mathrm{h}}^{*}=\mathrm{n}_{\mathrm{h}}, \mathrm{n}_{\mathrm{f}}^{*}=\left(\mathrm{n}_{\mathrm{f}}-\mathrm{m}\right)$, and $\mathrm{n}_{\mathrm{m}}^{*}=\mathrm{m}$, respectively. Then for $\mathrm{j}=\mathrm{h}, \mathrm{f}, \mathrm{m}$, the shares of each of these firms in domestic is defined by:

$$
s_{j} \equiv\left[\frac{n_{j}^{*} p_{j} x_{j}}{n_{h} p_{h} x_{h}+\left(n_{f}-m\right) p_{f} x_{f}+m p_{m} x_{m}}\right]=\left[\frac{n_{j}^{*} p_{h}^{1-\varepsilon}}{n_{h} p_{h}^{1-\varepsilon}+\left(n_{f}-m\right) p_{f}^{1-\varepsilon}+m p_{m}^{1-\varepsilon}}\right]
$$

where the equality in (A1) follows from (3).

Using (A1), (3) and (4), the derivatives of the revenues $\mathrm{p}_{\mathrm{j}} \mathrm{x}_{\mathrm{j}}$ with respect to $\mathrm{m}$ are:

$$
\frac{d\left(p_{j} x_{j}\right)}{d m}=-\left(\frac{\varepsilon-\theta}{\varepsilon-1}\right)\left(p_{m} x_{m}-p_{f} x_{f}\right)\left(\frac{s_{j}}{n_{j}^{*}}\right) \text { for } j=h, f, m
$$

In addition, we calculate from (A1)-(A2) that,

$$
\frac{d s_{j}}{d m}=\left\{\begin{array}{cc}
-\left[\left(\frac{s_{m}}{m}\right)-\frac{s_{f}}{\left(n_{f}-m\right)}\right] s_{h} & \text { for } j=h \\
{\left[\left(\frac{s_{m}}{m}\right) s_{f}+\frac{s_{f}}{\left(n_{f}-m\right)}\left(1-s_{f}\right)\right]} & \text { for } j=f \\
{\left[\left(\frac{s_{m}}{m}\right)\left(1-s_{m}\right)+\frac{s_{f}}{\left(n_{f}-m\right)} s_{m}\right]} & \text { for } j=m
\end{array}\right.
$$

Finally, we use (3), (4) and (6b) to compute:

$$
\begin{gathered}
\frac{d\left(p_{f} x_{f}\right)}{d \tau}=\frac{\varepsilon x_{f}}{(\varepsilon-1)}\left[1-\varepsilon\left(1-s_{f}\right)-\theta s_{f}\right] \\
\frac{d\left(p_{j} x_{j}\right)}{d \tau}=\varepsilon\left(\frac{p_{j} x_{j}}{p_{f}}\right)\left(\frac{\varepsilon-\theta}{\varepsilon-1}\right) s_{f}>0, \text { for } j=h, m .
\end{gathered}
$$




\section{$\underline{\text { Proof of Lemma } 1}$}

Using (A2), we compute the derivative of $G$ as:

$$
\begin{aligned}
\frac{\partial \mathrm{G}}{\partial \mathrm{m}}= & \left(\frac{\varepsilon-\theta}{\varepsilon-1}\right)\left(\mathrm{p}_{\mathrm{m}} \mathrm{x}_{\mathrm{m}}-\mathrm{p}_{\mathrm{f}} \mathrm{x}_{\mathrm{f}}\right)\left[\frac{\alpha}{(\theta-1)}+\frac{\beta \mathrm{s}_{\mathrm{h}}}{\varepsilon}+\frac{\tau \mathrm{s}_{\mathrm{f}}}{\mathrm{p}_{\mathrm{f}}}+\frac{(\mathrm{w}-1)(\varepsilon-1) \mathrm{s}_{\mathrm{m}}}{\mathrm{w} \varepsilon}+\frac{\lambda \mathrm{s}_{\mathrm{m}}}{\varepsilon}\right] \\
& -\mathrm{p}_{\mathrm{f}} \mathrm{x}_{\mathrm{f}}\left[\frac{1}{(\theta-1)}+\frac{\tau}{\mathrm{p}_{\mathrm{f}}}\right]+\alpha \mathrm{p}_{\mathrm{m}} \mathrm{x}_{\mathrm{m}}\left[\frac{1}{(\theta-1)}+\frac{(\mathrm{w}-1)(\varepsilon-1)}{\mathrm{w} \varepsilon}\right],
\end{aligned}
$$

which can be re-written as (12). Substituting $\mathrm{s}_{\mathrm{m}}=1-\mathrm{s}_{\mathrm{h}}-\mathrm{s}_{\mathrm{f}}$, this can be re-arranged as:

$$
\begin{aligned}
& \frac{\partial \mathrm{G}}{\partial \mathrm{m}}=\mathrm{p}_{\mathrm{f}} \mathrm{x}_{\mathrm{f}}\left[\frac{\alpha(\mathrm{w}-1)(\varepsilon-1)}{\mathrm{w} \varepsilon}+\frac{\lambda}{\varepsilon}-\frac{\tau}{\mathrm{p}_{\mathrm{f}}}\right]+\left(\frac{\theta-1}{\varepsilon-1}\right)\left(\mathrm{p}_{\mathrm{m}} \mathrm{x}_{\mathrm{m}}-\mathrm{p}_{\mathrm{f}} \mathrm{x}_{\mathrm{f}}\right)\left[\frac{\alpha}{(\theta-1)}+\frac{\alpha(\mathrm{w}-1)(\varepsilon-1)}{\mathrm{w} \varepsilon}+\frac{\lambda}{\varepsilon}\right] \\
& \quad+\left(\frac{\varepsilon-\theta}{\varepsilon-1}\right)\left(\mathrm{p}_{\mathrm{m}} \mathrm{x}_{\mathrm{m}}-\mathrm{p}_{\mathrm{f}} \mathrm{x}_{\mathrm{f}}\right)\left\{\mathrm{s}_{\mathrm{h}}\left[\frac{\alpha(\mathrm{w}-1)(\varepsilon-1)}{\mathrm{w} \varepsilon}+\frac{\lambda}{\varepsilon}-\frac{\beta}{\varepsilon}\right]+\mathrm{s}_{\mathrm{f}}\left[\frac{\alpha(\mathrm{w}-1)(\varepsilon-1)}{\mathrm{w} \varepsilon}+\frac{\lambda}{\varepsilon}-\frac{\tau}{\mathrm{p}_{\mathrm{f}}}\right]\right\}(\mathrm{A} 6)
\end{aligned}
$$

Using (A1)-(A3), we compute from (A6),

$$
\begin{aligned}
& \frac{\partial^{2} \mathrm{G}}{\partial \mathrm{m}^{2}}=-\left(\frac{\varepsilon-\theta}{\varepsilon-1}\right)\left[\frac{\mathrm{s}_{\mathrm{m}}}{\mathrm{m}}-\frac{\mathrm{s}_{\mathrm{f}}}{\left(\mathrm{n}_{\mathrm{f}}-\mathrm{m}\right)}\right] \frac{\partial \mathrm{G}}{\partial \mathrm{m}} \\
&+\left(\frac{\varepsilon-\theta}{\varepsilon-1}\right)\left(\mathrm{p}_{\mathrm{m}} \mathrm{x}_{\mathrm{m}}-\mathrm{p}_{\mathrm{f}} \mathrm{x}_{\mathrm{f}}\right)\left\{\left[\frac{\beta}{\varepsilon}-\frac{\alpha(\mathrm{w}-1)(\varepsilon-1)}{w \varepsilon}-\frac{\lambda}{\varepsilon}\right]\left[\frac{\mathrm{s}_{\mathrm{m}}}{\mathrm{m}}-\frac{\mathrm{s}_{\mathrm{f}}}{\left(\mathrm{n}_{\mathrm{f}}-\mathrm{m}\right)}\right] \mathrm{s}_{\mathrm{h}}\right. \\
&\left.+\left[\frac{\tau}{\mathrm{p}_{\mathrm{f}}}-\frac{\alpha(\mathrm{w}-1)(\varepsilon-1)}{\mathrm{w} \varepsilon}-\frac{\lambda}{\varepsilon}\right]\left[\left(\frac{\mathrm{s}_{\mathrm{m}}}{\mathrm{m}}\right) \mathrm{s}_{\mathrm{f}}+\frac{\mathrm{s}_{\mathrm{f}}}{\left(\mathrm{n}_{\mathrm{f}}-\mathrm{m}\right)}\left(1-\mathrm{s}_{\mathrm{f}}\right)\right]\right\}
\end{aligned}
$$

Eq. (8) ensures that $p_{m} x_{m}-p_{f} x_{f}>0$. Then the hypothesis of part (a) implies that $\partial^{2} G / \partial m^{2} \leq 0$ when $\partial \mathrm{G} / \partial \mathrm{m}=0$, so that $\mathrm{G}$ is quasi-concave When $\theta>1$ we also obtain $\partial \mathrm{G} / \partial \mathrm{m}>0$ from (A6), 
while when $\theta<1$ then slightly stronger conditions are needed. Under the hypothesis of part (b), we see that $\partial \mathrm{G} / \partial \mathrm{m}=0$ in $(\mathrm{A} 7)$ implies that $\partial^{2} \mathrm{G} / \partial \mathrm{m}^{2} \geq 0$, so that $\mathrm{G}$ is quasi-convex.

\section{Proof of Lemma 2}

Treating (9) as an equality, the derivatives with respect to $\mathrm{m}$ are given by (A2). Then totally differentiating (9), we obtain,

$$
\frac{\mathrm{dm}}{\mathrm{d} \lambda}=-\left(\frac{\varepsilon-1}{\varepsilon-\theta}\right) \frac{\mathrm{mp}_{\mathrm{m}} \mathrm{x}_{\mathrm{m}}}{\left(\mathrm{p}_{\mathrm{m}} \mathrm{x}_{\mathrm{m}}-\mathrm{p}_{\mathrm{f}} \mathrm{x}_{\mathrm{f}}\right)\left[(1-\lambda) \mathrm{s}_{\mathrm{m}}-\mathrm{ms}_{\mathrm{f}} /\left(\mathrm{n}_{\mathrm{f}}-\mathrm{m}\right)\right]}<0 .
$$

Again treating (9) as an equality, we can totally differentiate and use (A2) and (A4) to obtain,

$$
\frac{\mathrm{dm}}{\mathrm{d} \tau} \mathrm{p}_{\mathrm{f}}=\left(\frac{\mathrm{m} \varepsilon}{\varepsilon-\theta}\right)\left\{\frac{(\varepsilon-\theta)\left[(1-\lambda) \mathrm{p}_{\mathrm{m}} \mathrm{x}_{\mathrm{m}}-\mathrm{p}_{\mathrm{f}} \mathrm{x}_{\mathrm{f}}\right] \mathrm{s}_{\mathrm{f}}+(\varepsilon-1) \mathrm{p}_{\mathrm{f}} \mathrm{x}_{\mathrm{f}}}{\left(\mathrm{p}_{\mathrm{m}} \mathrm{x}_{\mathrm{m}}-\mathrm{p}_{\mathrm{f}} \mathrm{x}_{\mathrm{f}}\right)\left[(1-\lambda) \mathrm{s}_{\mathrm{m}}-\mathrm{ms}_{\mathrm{f}} /\left(\mathrm{n}_{\mathrm{f}}-\mathrm{m}\right)\right]}\right\}>0
$$

\section{Proof of Proposition 1}

(a) The first-order condition for an interior maximum of (13) with respect to $\lambda_{i}$ is:

$$
\frac{\mathrm{dG}_{\mathrm{i}}}{\mathrm{d} \lambda_{\mathrm{i}}}=\frac{\partial \mathrm{G}_{\mathrm{i}}}{\partial \lambda_{\mathrm{i}}}+\frac{\partial \mathrm{G}_{\mathrm{i}}}{\partial \mathrm{m}_{\mathrm{i}}} \frac{\partial \mathrm{m}_{\mathrm{i}}}{\mathrm{d} \lambda_{\mathrm{i}}}=0
$$

Noting that $\partial \mathrm{G}_{\mathrm{i}} / \partial \lambda_{\mathrm{i}}=\mathrm{m}_{\mathrm{i}} \pi_{\mathrm{mi}}$, and using (A9), this condition is expressed as (14).

To check the second-order condition, for fixed $\tau$ we solve for the profit tax $\lambda_{\mathrm{i}}=\phi_{\mathrm{i}}\left(\mathrm{m}_{\mathrm{i}}, \tau\right)$ as a function of the number of multinational firms. Then we re-express the optimization problem (13) as choosing $m_{i}$ subject to $0 \leq m_{i} \leq n_{f}$ to maximize $\Sigma_{i} G_{i}\left[m_{i}, \phi_{i}\left(m_{i}, \tau\right), \tau\right]$. The first-derivative 
is $\mathrm{dG}_{\mathrm{i}} / \mathrm{dm}_{\mathrm{i}}=\partial \mathrm{G}_{\mathrm{i}} / \partial \mathrm{m}_{\mathrm{i}}+\mathrm{m}_{\mathrm{i}} \pi_{\mathrm{mi}_{\mathrm{i}}} \partial \phi_{\mathrm{i}} / \partial \mathrm{m}_{\mathrm{i}}=\partial \mathrm{G}_{\mathrm{i}} / \partial \mathrm{m}_{\mathrm{i}}+\mathrm{m}_{\mathrm{i}} \pi_{\mathrm{mi}_{\mathrm{i}}} /\left(\partial \mathrm{m}_{\mathrm{i}} / \partial \lambda_{\mathrm{i}}\right)$. Using (A1)-(A3), (A7) and (A9), it can be shown that:

$$
\begin{gathered}
\frac{\mathrm{d}^{2} \mathrm{G}_{\mathrm{i}}}{\mathrm{dm}_{\mathrm{i}}^{2}}=\left[(\mathrm{A} 7) \text { with } \frac{\partial \mathrm{G}_{\mathrm{i}}}{\partial \mathrm{m}_{\mathrm{i}}} \text { replaced by } \frac{\mathrm{dG}_{\mathrm{i}}}{\mathrm{dm}_{\mathrm{i}}}\right]-2 \lambda_{\mathrm{i}} \pi_{\mathrm{mi}}\left(\frac{\varepsilon-\theta}{\varepsilon-1}\right) \frac{\mathrm{m}_{\mathrm{i}} \mathrm{s}_{\mathrm{fi}}}{\left(\mathrm{n}_{\mathrm{f}}-\mathrm{m}_{\mathrm{i}}\right)^{2}} \\
+\lambda_{\mathrm{i}}\left(\frac{\varepsilon-\theta}{\varepsilon-1}\right)\left[\left(1-\lambda_{\mathrm{i}}\right)\left(\frac{\mathrm{s}_{\mathrm{mi}}}{\mathrm{m}_{\mathrm{i}}}\right)-\frac{\mathrm{s}_{\mathrm{fi}}}{\left(\mathrm{n}_{\mathrm{f}}-\mathrm{m}_{\mathrm{i}}\right)}\right]\left\{2 \pi_{\mathrm{mi}}+\mathrm{F}_{\mathrm{it}}-\mathrm{s}_{\mathrm{mi}}\left(\mathrm{F}_{\mathrm{it}}+\lambda_{\mathrm{i}} \pi_{\mathrm{mi}}\right)-\left(\frac{\varepsilon-\theta}{\varepsilon-1}\right) \mathrm{s}_{\mathrm{mi}}\left(2 \mathrm{~F}_{\mathrm{it}}+\lambda_{\mathrm{i}} \pi_{\mathrm{mi}}\right)\right\}
\end{gathered}
$$

When $\mathrm{dG} / \mathrm{dm}=0$, then $\mathrm{d}^{2} \mathrm{G} / \mathrm{d}^{2} \mathrm{~m} \leq 0$ provided that the second line is non-negative. Using $\pi_{\mathrm{mi}}=$ $\lambda_{\mathrm{i}} \pi_{\mathrm{mi}}+\mathrm{F}_{\mathrm{it}}+\pi_{\mathrm{f}}$, a sufficient condition for this is $\mathrm{s}_{\mathrm{mi}} \leq(\varepsilon-1) /(\varepsilon-\theta)$.

To evaluate this second-derivative numerically, we can divide by total expenditure on the differentiated good, so that $\pi_{\mathrm{mi}}=\mathrm{p}_{\mathrm{mi}} \mathrm{x}_{\mathrm{mi}} / \varepsilon$ becomes substitute for $\mathrm{s}_{\mathrm{mi}} /(\mathrm{m} \varepsilon)$. We also need to specify the fixed costs $F_{i t}$, and we choose the conservative value of zero, which leads to a higher value for the second-derivative.

\section{Proof of Proposition 2}

Differentiating (11) using (A4), the partial derivative with respect to $\tau$ is,

$$
\left(\frac{\partial \mathrm{G}_{\mathrm{i}}}{\partial \tau}\right) \mathrm{p}_{\mathrm{f}}=\left(\frac{\varepsilon-\theta}{\varepsilon-1}\right) \mathrm{s}_{\mathrm{fi}}\left(\mathrm{G}_{\mathrm{i}}-\alpha \mathrm{L}_{\mathrm{i}}\right)+\left(\mathrm{n}_{\mathrm{f}}-\mathrm{m}_{\mathrm{i}}\right) \mathrm{p}_{\mathrm{f}} \mathrm{x}_{\mathrm{fi}}\left[1-\frac{\varepsilon \alpha}{(\theta-1)}-\frac{\varepsilon \tau}{\mathrm{p}_{\mathrm{f}}}\right]
$$

Substituting for $\mathrm{G}_{\mathrm{i}}$ from (11), and simplifying, we obtain (21). To obtain (22), we compute $\mathrm{d} \lambda_{\mathrm{i}} /\left.\mathrm{d} \tau\right|_{\mathrm{m}_{\mathrm{i}}}=-\left(\partial \mathrm{m}_{\mathrm{i}} / \partial \tau\right) /\left(\partial \mathrm{m}_{\mathrm{i}} / \partial \lambda_{\mathrm{i}}\right)$ from (A9) and (A10), and simplify. 


\section{References}

Bernheim, Douglas B. and Michael D. Whinston, 1986, "Menu Auctions, Resource Allocation, and Economic Influence," Quarterly Journal of Economics, 101, 1-31.

Brecher, Richard and Carlos Diaz-Alejandro, 1977, "Tariffs, Foreign Capital and Immiserizing Growth," Journal of International Economics, 7, 317-322.

Feenstra, Robert C., Wen Hai, Wing T. Woo, and Shunli Yao, 1998 "The U.S.-China Bilateral Trade Balance: Its Size and Determinants,’, NBER Working Paper no. 6598.

Feenstra, Robert C., Wen Hai, Wing T. Woo, and Shunli Yao, 1999, "Discrepancies in International Data: An Application to China-Hong Kong Entrepôt Trade," American Economic Review, May, forthcoming.

Grossman, Gene M and Elhanan Helpman, 1994, "Protection for Sale," American Economic Review, 84, 833-850.

Grossman, Gene M and Elhanan Helpman, 1996, "Foreign Investment with Endogenous Protection," in Robert C. Feenstra, Gene M. Grossman and Douglas A. Irwin, eds., The Political Economy of Trade Policy: Papers in Honor of Jagdish Bhagwati, Cambridge: MIT Press, 199-224.

Grub, Phillip Donald and Jian Hai Lin, 1991, Foreign Direct Investment in China, New York: Quorum Books.

Lardy, Nicholas, 1992, Foreign Trade and Economic Reform in China, 1978-1990. New York: Cambridge University Press.

Li, David D. and Qi Chen, 1998, "Why Aren’t Foreign Direct Investments Always Welcome? A Political Economy Analysis," University of Michigan, mimeo.

Naughton, Barry, 1995, Growing Out of the Plan: Chinese Economic Reform, 1978-1993. New York: Cambridge University Press.

Naughton, Barry, 1996, "China's Emergence and Prospects as a Trading Nation,” Brookings Papers on Economic Activity, 2: 1996, pp. 273-343.

Pomfret, Richard W. T., 1991, Investing in China: Ten Years of the Open Door Policy. Ames: Iowa State University Press.

Rosen, Daniel, 1998, Behind the Open Door: Foreign Firms in China, Institute for International Economics, Washington, D.C.

Sachs, Jeffrey D. and Wing Thye Woo, 1997, "Understanding China's Economic Performance," NBER Working Paper no. 5935, February. 
Steinfeld, Edward, 1998, Forging Reform in China: The Fate of State-Owned Industry, New York: Cambridge University Press.

Wei, Shang-Jin, 1998, “Why Does China Attract so Little Foreign Investment?” Harvard University and NBER, mimeo.

World Bank, 1997, China Engaged: Integration with the Global Economy. Washington, D.C.

Xinjiang Statistical Bureau , 1998, "China's Regional Economy in the 17 Years Since Reform and Liberalization" electronic database on diskette.

Young, Alwyn, 1997, “The Razor's Edge: Distortions and Incremental Reform in the People's Republic of China, University of Chicago, mimeo. 
Table 1: Selected Data in 1995

\begin{tabular}{|c|c|c|c|c|c|c|}
\hline & \multicolumn{3}{|c|}{ Output Multinational State-owned } & \multirow{2}{*}{$\begin{array}{l}\text { Import } \\
\text { Share }\end{array}$} & \multirow{2}{*}{$\begin{array}{c}\text { Wage } \\
\text { Premium }\end{array}$} & \multirow[t]{2}{*}{ Tariffs } \\
\hline & & Share & Share & & & \\
\hline Beijing & 1909 & 0.215 & 0.555 & 0.075 & 0.366 & 0.413 \\
\hline Tianjin & 2094 & 0.240 & 0.284 & 0.043 & 0.522 & 0.306 \\
\hline \multicolumn{7}{|c|}{ Include "Open Coastal Cities" or SEZ } \\
\hline Liaoning & 4975 & 0.042 & 0.389 & 0.022 & 0.475 & 0.227 \\
\hline Hebei & 3996 & 0.066 & 0.327 & 0.007 & 0.360 & 0.289 \\
\hline Shandong & 8456 & 0.054 & 0.274 & 0.007 & 0.308 & 0.282 \\
\hline Jiangsu & 11813 & 0.102 & 0.176 & 0.008 & 0.353 & 0.223 \\
\hline Shanghai & 5129 & 0.290 & 0.294 & 0.080 & 0.452 & 0.163 \\
\hline Zhejiang & 8088 & 0.075 & 0.082 & 0.010 & 0.270 & 0.240 \\
\hline Fujian & 2801 & 0.270 & 0.068 & 0.035 & 0.387 & 0.298 \\
\hline Guangdong & 9535 & 0.271 & 0.000 & 0.075 & 0.330 & 0.215 \\
\hline Guangxi & 1666 & 0.065 & 0.357 & 0.014 & 0.357 & 0.252 \\
\hline Hainan & 193 & 0.204 & 0.054 & 0.348 & 0.436 & 0.172 \\
\hline Average & 5665 & 0.144 & 0.202 & 0.061 & 0.373 & 0.236 \\
\hline \multicolumn{7}{|c|}{ Do not include “Open Coastal Cities” or SEZ } \\
\hline Heilongjiang & 2204 & 0.026 & 0.648 & 0.011 & 0.582 & 0.264 \\
\hline Jilin & 1429 & 0.062 & 0.576 & 0.054 & 0.367 & 0.174 \\
\hline Inner Mongolia & 782 & 0.048 & 0.606 & 0.021 & 0.232 & 0.320 \\
\hline Shanxi & 1754 & 0.017 & 0.433 & 0.005 & 0.399 & 0.216 \\
\hline Henan & 4715 & 0.041 & 0.323 & 0.006 & 0.352 & 0.294 \\
\hline Anhui & 3156 & 0.032 & 0.292 & 0.005 & 0.578 & 0.241 \\
\hline Hubei & 4103 & 0.037 & 0.354 & 0.013 & 0.350 & 0.195 \\
\hline Jiangxi & 1291 & 0.041 & 0.495 & 0.008 & 0.468 & 0.257 \\
\hline Hunan & 2451 & 0.034 & 0.385 & 0.009 & 0.437 & 0.209 \\
\hline Guizhou & 557 & 0.032 & 0.641 & 0.015 & 0.430 & 0.139 \\
\hline Yunnan & 1207 & 0.028 & 0.644 & 0.038 & 0.270 & 0.234 \\
\hline Sichuan & 4426 & 0.034 & 0.374 & 0.012 & 0.453 & 0.186 \\
\hline Tibet & 9 & 0.000 & 0.725 & 0.250 & 0.621 & 0.321 \\
\hline Qinghai & 149 & 0.006 & 0.827 & 0.005 & 0.463 & 0.157 \\
\hline Shaanxi & 1183 & 0.045 & 0.563 & 0.018 & 0.533 & 0.234 \\
\hline Gansu & 825 & 0.040 & 0.645 & 0.013 & 0.396 & 0.146 \\
\hline Ningxia & 198 & 0.093 & 0.665 & 0.006 & 0.352 & 0.170 \\
\hline Xinjiang & 803 & 0.020 & 0.715 & 0.009 & 0.245 & 0.092 \\
\hline Average & 1736 & 0.035 & 0.551 & 0.028 & 0.418 & 0.214 \\
\hline
\end{tabular}

$\underline{\text { Notes }}$

Output is measured in 100 million $\mathrm{RMB}$, where $8 \mathrm{RMB} \approx \$ 1$. The shares of domestic spending on multinationals, state-owned enterprises and imports are measured according to Method B, as described in the text. The wage premium shown is unweighted, and equals wages paid by multinationals minus that in urban collectives, divided by that in multinationals. The tariff variable equals a weighted average of the 1996 ad valorem tariffs in each province. 
Table 2: Dependent Variable Multinational Share of Provincial Spending

\begin{tabular}{|c|c|c|c|c|c|}
\hline \multirow[b]{2}{*}{$\begin{array}{c}\text { Independent } \\
\text { Variable: }\end{array}$} & \multirow[b]{2}{*}{ Coefficient } & \multicolumn{2}{|c|}{$\frac{\text { Method A }}{\text { (no correction for exports) }}$} & \multicolumn{2}{|c|}{$\frac{\text { Method B }}{\text { (correcting for exports) }}$} \\
\hline & & $\begin{array}{c}\text { Unweighted } \\
\text { Wages }\end{array}$ & $\begin{array}{c}\text { Weighted } \\
\text { Wages }\end{array}$ & $\begin{array}{l}\text { Unweighted } \\
\text { Wages }\end{array}$ & $\begin{array}{c}\text { Weighted } \\
\text { Wages }\end{array}$ \\
\hline $\begin{array}{l}\text { State-owned } \\
\text { share, } s_{\text {mit }}\end{array}$ & $-\beta$ & $\begin{array}{l}-1.43 \\
(0.36)\end{array}$ & $\begin{array}{l}-0.99 \\
(0.25)\end{array}$ & $\begin{array}{l}-1.58 \\
(0.54)\end{array}$ & $\begin{array}{l}-1.20 \\
(0.34)\end{array}$ \\
\hline $\begin{array}{l}\text { Wage premium, } \\
\left(\mathrm{w}_{\mathrm{it}}-1\right) / \mathrm{w}_{\mathrm{it}}\end{array}$ & $\frac{\alpha(\varepsilon-1)(\theta-1)}{(\varepsilon-\theta)}$ & $\begin{array}{l}-1.10 \\
(0.35)\end{array}$ & $\begin{array}{l}-0.42 \\
(0.23)\end{array}$ & $\begin{array}{l}-1.14 \\
(0.49)\end{array}$ & $\begin{array}{l}-0.71 \\
(0.31)\end{array}$ \\
\hline $\begin{array}{l}\text { Wage premium* } \\
\text { (state+import share), } \\
{\left[\left(\mathrm{w}_{\mathrm{it}}-1\right) / \mathrm{w}_{\mathrm{it}}\right]\left(\mathrm{s}_{\mathrm{mit}}+\mathrm{s}_{\mathrm{fit}}\right)}\end{array}$ & $\alpha(\varepsilon-1)$ & $\begin{array}{c}1.58 \\
(0.49)\end{array}$ & $\begin{array}{l}0.623 \\
(0.33)\end{array}$ & $\begin{array}{c}1.74 \\
(0.73)\end{array}$ & $\begin{array}{c}1.11 \\
(0.46)\end{array}$ \\
\hline $\begin{array}{l}\text { Tariff*import } \\
\text { share, } \tau_{\mathrm{i}} \mathrm{s}_{\text {fit }}\end{array}$ & $-\varepsilon$ & $\begin{array}{l}-6.31 \\
(2.61)\end{array}$ & $\begin{array}{l}-4.94 \\
(2.29)\end{array}$ & $\begin{array}{r}-14.08 \\
(6.30)\end{array}$ & $\begin{array}{r}-11.71 \\
(3.77)\end{array}$ \\
\hline $\begin{array}{l}\text { FDI stock* } \\
\text { import share }\end{array}$ & $1 / \mathrm{n}_{\mathrm{f}}$ & $\begin{array}{c}0.014 \\
(0.010)\end{array}$ & $\begin{array}{c}0.023 \\
(0.011)\end{array}$ & $\begin{array}{l}-0.041 \\
(0.029)\end{array}$ & $\begin{array}{l}-0.027 \\
(0.024)\end{array}$ \\
\hline $\mathrm{R}^{2}(\mathrm{~N}=297)$ & & 0.514 & 0.490 & 0.129 & 0.139 \\
\hline Fixed effects & & Yes & Yes & Yes & Yes \\
\hline$\chi^{2}$ test for exogeneity & & 8.76 & 7.81 & 9.71 & 7.07 \\
\hline
\end{tabular}

Notes:

The sample consists of 29 provinces (excluding Tibet) over 1984-1995, using fixed effects for provinces and for time; only provinces with positive multinational output are included ( $\mathrm{N}=297)$. The regressions are estimated with TSLS, using as instruments the sales of state-owned firms, value of imports, lagged FDI stock, output, wage premium, and the interaction between the wage premium and these four variables. In addition, the sales of collectives and of independent firms are included as control variables and as instruments, though these coefficient are not reported above. The weighted regression use provincial value of output as a weight. Standard errors are reported in parentheses.

The test for exogeneity of instruments, reported in the last line, is constructed by regressing the residual from the structural equation on the instruments. The value reported equals 297 times the $\mathrm{R}^{2}$ from this auxiliary regression, and is distributed $\chi^{2}(4)$ under the null hypothesis that the instruments are exogenous. The 5\% critical values for this test statistic is 9.49 . 
Table 3: Coefficient Estimates, by Time Period

\begin{tabular}{|c|c|c|c|c|c|}
\hline \multirow[b]{2}{*}{$\begin{array}{c}\text { Independent } \\
\text { Variable: }\end{array}$} & \multirow[b]{2}{*}{ Coefficient } & \multicolumn{2}{|c|}{$\frac{\text { Method A }}{\text { (no correction for exports) }}$} & \multicolumn{2}{|c|}{$\frac{\text { Method B }}{\text { (correcting for exports) }}$} \\
\hline & & $\begin{array}{c}\text { Unweighted } \\
\text { Wages }\end{array}$ & $\begin{array}{c}\text { Weighted } \\
\text { Wages }\end{array}$ & $\begin{array}{c}\text { Unweighted } \\
\text { Wages }\end{array}$ & $\begin{array}{c}\text { Weighted } \\
\text { Wages } \\
\end{array}$ \\
\hline \multirow[t]{3}{*}{$\begin{array}{l}1984-1995 \\
(N=297)\end{array}$} & $\alpha$ & $\begin{array}{c}0.30 \\
(0.09)\end{array}$ & $\begin{array}{c}0.16 \\
(0.08)\end{array}$ & $\begin{array}{c}0.13 \\
(0.03)\end{array}$ & $\begin{array}{c}0.10 \\
(0.04)\end{array}$ \\
\hline & $\beta$ & $\begin{array}{c}1.43 \\
(0.36)\end{array}$ & $\begin{array}{c}0.99 \\
(0.25)\end{array}$ & $\begin{array}{c}1.58 \\
(0.54)\end{array}$ & $\begin{array}{c}1.20 \\
(0.38)\end{array}$ \\
\hline & $\varepsilon$ & $\begin{array}{c}6.31 \\
(2.61)\end{array}$ & $\begin{array}{l}4.94 \\
(2.30)\end{array}$ & $\begin{array}{l}14.08 \\
(6.30)\end{array}$ & $\begin{array}{l}11.71 \\
(3.78)\end{array}$ \\
\hline \multirow[t]{3}{*}{$\begin{array}{l}1988-1995 \\
(N=225)\end{array}$} & $\alpha$ & $\begin{array}{c}0.34 \\
(0.15)\end{array}$ & $\begin{array}{c}0.18 \\
(0.13)\end{array}$ & $\begin{array}{c}0.32 \\
(0.18)\end{array}$ & $\begin{array}{c}0.29 \\
(0.26)\end{array}$ \\
\hline & $\beta$ & $\begin{array}{c}1.19 \\
(0.38)\end{array}$ & $\begin{array}{c}0.68 \\
(0.20)\end{array}$ & $\begin{array}{c}1.21 \\
(0.32)\end{array}$ & $\begin{array}{c}1.06 \\
(0.34)\end{array}$ \\
\hline & $\varepsilon$ & $\begin{array}{c}5.11 \\
(2.90)\end{array}$ & $\begin{array}{c}4.10 \\
(2.61)\end{array}$ & $\begin{array}{c}5.29 \\
(3.03)\end{array}$ & $\begin{array}{c}4.61 \\
(3.57)\end{array}$ \\
\hline \multirow[t]{3}{*}{$\begin{array}{l}1990-1995 \\
(N=171)\end{array}$} & $\alpha$ & $\begin{array}{c}0.47 \\
(0.40)\end{array}$ & $\begin{array}{c}0.32 \\
(0.52)\end{array}$ & $\begin{array}{c}0.27 \\
(0.13)\end{array}$ & $\begin{array}{c}0.42 \\
(0.61)\end{array}$ \\
\hline & $\beta$ & $\begin{array}{c}1.03 \\
(0.38)\end{array}$ & $\begin{array}{c}0.45 \\
(0.15)\end{array}$ & $\begin{array}{c}1.19 \\
(0.36)\end{array}$ & $\begin{array}{c}1.06 \\
(0.34)\end{array}$ \\
\hline & $\varepsilon$ & $\begin{array}{c}3.29 \\
(2.59)\end{array}$ & $\begin{array}{c}2.05 \\
(1.78)\end{array}$ & $\begin{array}{c}5.47 \\
(2.63)\end{array}$ & $\begin{array}{c}3.31 \\
(3.28)\end{array}$ \\
\hline
\end{tabular}

$\underline{\text { Notes }}$

Computed from the regressions reported in Table 2, but run over different time periods. 
Table 4: Welfare Effects of Tariffs Reductions (expressed as percent of import value)

\begin{tabular}{|c|c|c|c|c|c|c|c|}
\hline & \multirow[b]{2}{*}{$\begin{array}{c}\text { WTO } \\
\text { Tariffs }\end{array}$} & \multicolumn{3}{|c|}{ Example $1(\varepsilon=5, \theta=0.5)$} & \multicolumn{3}{|c|}{ Example $2(\varepsilon=10, \theta=2)$} \\
\hline & & $\begin{array}{l}\text { Direct } \\
(21)\end{array}$ & $\begin{array}{l}\text { Indirect } \\
\text { (22) }\end{array}$ & $\begin{array}{l}\text { Total } \\
\text { Effect }\end{array}$ & $\begin{array}{l}\text { Direct } \\
(21)\end{array}$ & $\begin{array}{l}\text { Indirect } \\
\text { (22) }\end{array}$ & $\begin{array}{l}\text { Total } \\
\text { Effect }\end{array}$ \\
\hline Beijing & 0.310 & 2.16 & -3.40 & -1.24 & 20.40 & -2.90 & 17.50 \\
\hline Tianjin & 0.230 & 0.70 & -2.58 & -1.88 & 10.29 & -2.15 & 8.14 \\
\hline \multicolumn{8}{|c|}{ Include "Open Coastal Cities" or SEZ } \\
\hline Liaoning & 0.170 & -1.35 & -0.82 & -2.16 & 4.49 & -0.76 & 3.73 \\
\hline Hebei & 0.217 & 0.83 & -0.81 & 0.02 & 10.16 & -0.70 & 9.47 \\
\hline Shandong & 0.212 & 1.06 & -1.55 & -0.48 & 9.90 & -1.46 & 8.44 \\
\hline Jiangsu & 0.167 & -0.08 & -2.10 & -2.18 & 5.27 & -1.97 & 3.30 \\
\hline Shanghai & 0.122 & -2.24 & -2.12 & -4.36 & 0.31 & -1.86 & -1.55 \\
\hline Zhejiang & 0.180 & 1.07 & -0.95 & 0.11 & 7.19 & -0.85 & 6.34 \\
\hline Fujian & 0.224 & 2.47 & -4.09 & -1.61 & 11.33 & -3.63 & 7.70 \\
\hline Guangdong & 0.161 & 0.17 & -5.10 & -4.94 & 4.49 & -4.83 & -0.34 \\
\hline Guangxi & 0.189 & -0.55 & -0.78 & -1.33 & 6.59 & -0.69 & 5.90 \\
\hline Hainan & 0.129 & -1.86 & -1.18 & -3.04 & 0.31 & -1.00 & -0.69 \\
\hline Average & 0.177 & -0.05 & -1.95 & -2.00 & 6.00 & -1.77 & 4.23 \\
\hline \multicolumn{8}{|c|}{ Do not include "Open Coastal Cities" or SEZ } \\
\hline Heilongjiang & 0.198 & -2.32 & -0.35 & -2.67 & 6.00 & -0.31 & 5.70 \\
\hline Jilin & 0.131 & -3.06 & -0.39 & -3.45 & 0.54 & -0.32 & 0.21 \\
\hline Inner Mongolia & 0.240 & -0.60 & -0.43 & -1.03 & 11.31 & -0.34 & 10.97 \\
\hline Shanxi & 0.162 & -1.64 & -0.13 & -1.77 & 3.82 & -0.11 & 3.72 \\
\hline Henan & 0.221 & 1.11 & -0.55 & 0.56 & 10.81 & -0.48 & 10.33 \\
\hline Anhui & 0.181 & -0.28 & -0.35 & -0.64 & 6.22 & -0.31 & 5.91 \\
\hline Hubei & 0.146 & -1.56 & -0.39 & -1.95 & 2.80 & -0.35 & 2.45 \\
\hline Jiangxi & 0.193 & -1.35 & -0.40 & -1.75 & 6.32 & -0.34 & 5.98 \\
\hline Hunan & 0.157 & -1.52 & -0.34 & -1.86 & 3.50 & -0.30 & 3.20 \\
\hline Guizhou & 0.104 & -3.08 & -0.14 & -3.22 & -0.59 & -0.11 & -0.70 \\
\hline Yunnan & 0.176 & -2.93 & -0.25 & -3.18 & 3.60 & -0.21 & 3.40 \\
\hline Sichuan & 0.140 & -1.78 & -0.38 & -2.16 & 2.21 & -0.34 & 1.87 \\
\hline Tibet & 0.241 & -4.46 & 0.00 & -4.46 & 6.12 & 0.00 & 6.12 \\
\hline Qinghai & 0.118 & -3.92 & -0.03 & -3.95 & -0.59 & -0.02 & -0.61 \\
\hline Shaanxi & 0.176 & -2.35 & -0.42 & -2.77 & 4.08 & -0.36 & 3.72 \\
\hline Gansu & 0.110 & -3.14 & -0.18 & -3.32 & -0.42 & -0.14 & -0.56 \\
\hline Ningxia & 0.128 & -3.35 & -0.45 & -3.81 & 0.25 & -0.36 & -0.11 \\
\hline Xinjiang & 0.069 & -2.67 & -0.06 & -2.73 & -1.43 & -0.05 & -1.48 \\
\hline Average & 0.160 & -2.16 & -0.29 & -2.45 & 3.59 & -0.25 & 3.34 \\
\hline
\end{tabular}

Notes:

Other parameters used in both examples are $\alpha=0.2$ and $\beta=1$. The values shown give the welfare effects of reducing tariffs from the level shown in Table 1 to that shown above. The direct effect is calculated using (21) in the text, and the indirect effect is calculated using (22) 


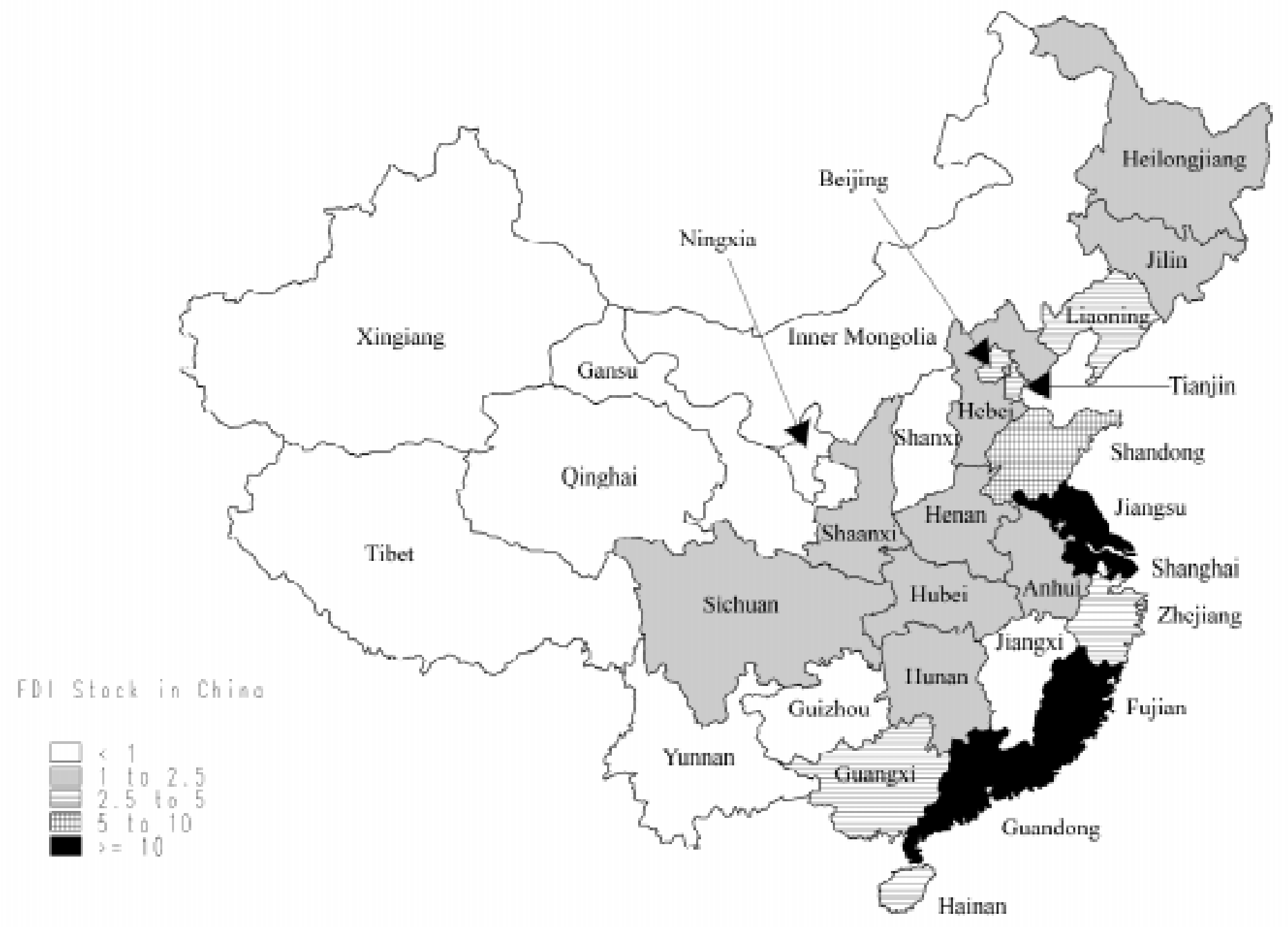

Figure 1 


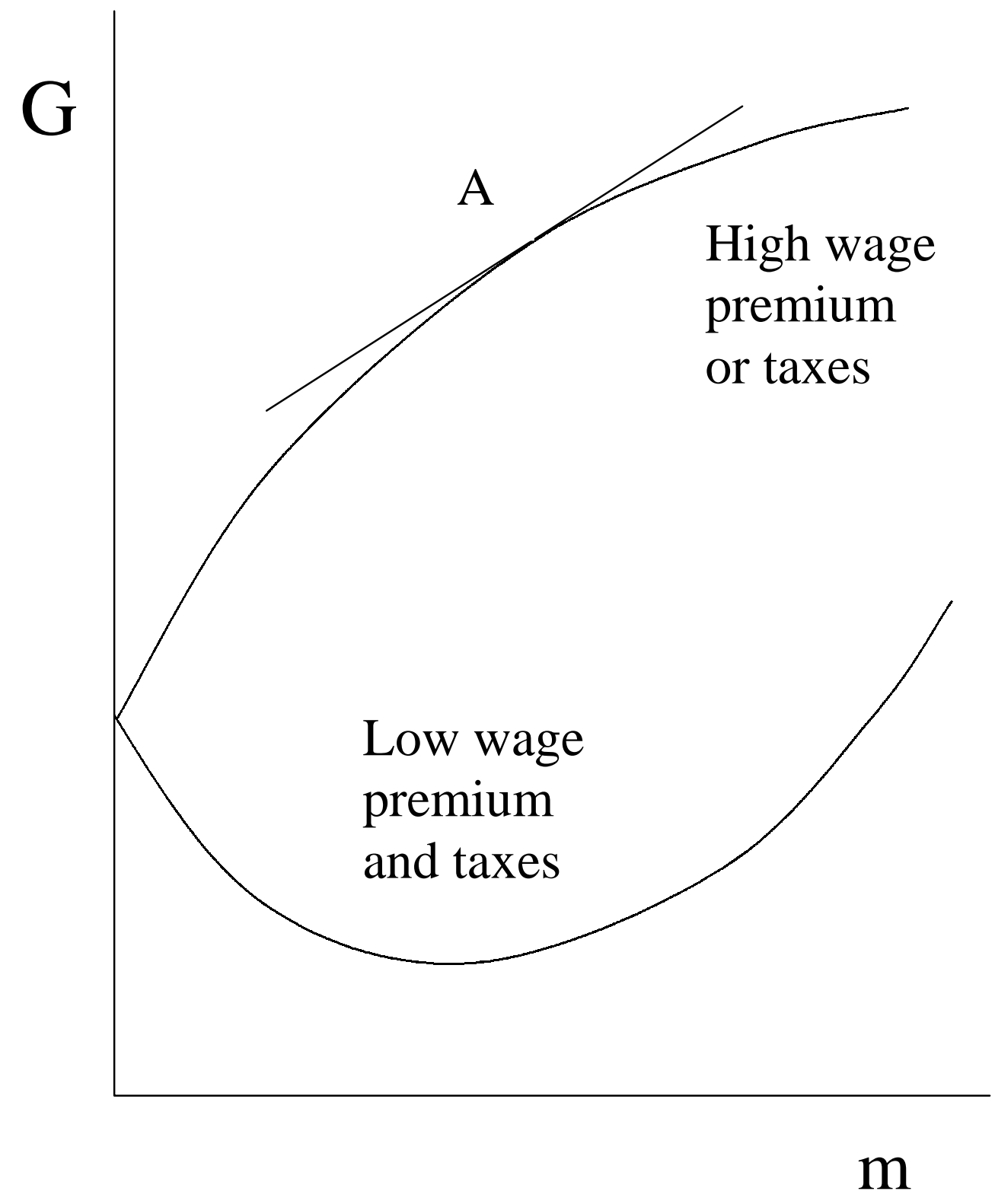

Figure 2 